\title{
LYCHNOPHORINAE (ASTERACEAE): A SURVEY OF ITS CHEMICAL CONSTITUENTS AND BIOLOGICAL ACTIVITIES $^{\#}$
}

\author{
Larissa Costa Keles, Nathalya Isabel de Melo, Gabriela de Paula Aguiar, Kamila Akemi Lima Wakabayashi, Carlos \\ Eduardo de Carvalho, Wilson Roberto Cunha e Antônio Eduardo Miller Crotti \\ Núcleo de Pesquisas em Ciências Exatas e Tecnológicas, Universidade de Franca, 14404-600 Franca - SP, Brasil \\ João Luis Callegari Lopes e Norberto Peporine Lopes* \\ Departamento de Física e Química, Faculdade de Ciências Farmacêuticas de Ribeirão Preto, Universidade de São Paulo, Av. do \\ Café, s/n, 14040-903 Ribeirão Preto - SP, Brasil
}

Recebido em 1/7/10; aceito em 21/9/10; publicado na web em 27/10/10

\begin{abstract}
LYCHNOPHORINAE (ASTERACEAE): A SURVEY OF ITS CHEMICAL CONSTITUENTS AND BIOLOGICAL ACTIVITIES. This work reviews the current literature about the chemical constituents and the biological activities of the subtribe Lychnophorinae (Vernonieae, Asteraceae). The notable secondary metabolites are sesquiterpene lactones of furanoheliangolide (goyazensolide and eremantholide types) and flavonoids. Some of its most investigated activities include its anti-inflammatory, analgesic, antimicrobial and cytotoxic activities, specially for the Lychnophora and Eremanthus species. The data presented on this paper not only displayed the role played by the Lychnophorinae species as a source of bioactive compounds, but also reinforced the need of further studies involving the species of such subtribe.
\end{abstract}

Keywords: Lychnophorinae; Lychnophora; sesquiterpene lactones.

\section{INTRODUCTION}

The subtribe Lychnophorinae belongs to the tribe Vernonieae of Asteraceae (Compositae). Most of its genera is found on the Brazilian's rupestrian vegetation (Table 1), which is present on the top of mountain chains on the Central and Southeastern regions of Brazil, especially in Minas Gerais, Bahia and Goiás, all presenting many species ${ }^{1}$ with a high degree of endemism.

Due to the taxonomic complexity of the Lychnophorinae, the genera of this subtribe have received considerable attention and several previous classification had to be changed.$^{2-4}$ In the most recent literature review of Lychnophorinae, Robinson ${ }^{3}$ considered the following ten genera: Anteremanthus H. Robinson, Chronopappus DC, Eremanthus Less. (syn. Sphaerophora Schultz-Bip = Paralychnophora MacLeish), Vanillosmopsis Schultz-Bip, Lychnophora Mart. (syn. Haplostephium Mart.), Lychnophoriopsis Schultz-Bip. (syn Episcothamnus H. Robinson), Minasia H. Robinson, Piptolepis Schultz-Bip, Pithecoseris Mart., and Proteopsis Mart \& Zucc. ex Schultz-Bip.

The terpenoid chemistry of this subtribe is mainly formed by furanoheliangolide sesquiterpene lactones (STL). ${ }^{4}$ The biological activities of these compounds were extensively investigated in the literature. Some species of the subtribe Lychnophorinae have also been employed in Brazilian traditional medicine. For example, the Lychnophora species, popularly known as "arnica da serra" or "falsa arnica" are used as analgesic and anti-inflammatory agents. ${ }^{5}$ Some species also have an economic importance, such as Eremanthus erythropappa, popularly known as "candeia" in Portuguese, whose essential oil is rich in $\alpha$-bisabolol and it is used in several cosmetic preparations. $^{6}$

Based on the economical and social importance of the subtribe Lychnophorinae, the goal of this work is to present a current literature review on the secondary metabolites and biological activities of the species of such subtribe in order to provide a basis for several

*e-mail: npelopes@fcfrp.usp.br

"This paper is dedicated to Prof. Hans Viertler different research areas such as botanic, pharmaceutical, medical and chemical fields.

\section{SECONDARY METABOLITES OF LYCHNOPHORINAE}

The chemical composition of Eremanthus and Lychnophora, the two most numerous genera of Lychnophorinae have been extensively investigated, as clearly seen by the number of papers dealing with this matter. On the other hand, some genera of this subtribe (i.e., Anteremanthus, Chronopappus and Pithecoseris) have not been submitted to phytochemical studies yet. Previous studies have been mostly focused on the investigation of extracts from the aerial parts or leaves of this subtribe, although a number of studies on roots have also been reported. ${ }^{7-16}$ The secondary metabolites mentioned earlier were usually identified and/or isolated from extracts obtained by maceration with non-polar ( $n$-hexane or petroleum ether) or moderately polar solvents (i.e., dichloromethane, chloroform, and ethyl acetate). Nevertheless, more recent studies have focused on the chemical composition of alcoholic and hydroalcoholic extracts. ${ }^{11,12,17,18}$ Alternative extraction methods, such as glandular trichomes microsampling ${ }^{19}$ and sonication-assisted extraction ${ }^{20}$ have also been investigated.

Figure 1 shows the main groups of secondary metabolites that have been described for the Lychnophorinae species, and theirs structures are shown in Figures 5-21. Terpenoids (70.2\%) and flavonoids (16.9\%) are the notable secondary metabolites of Lychnophorinae, although acetylene derivatives (2.6\%), quinic acid derivatives $(5.0 \%)$, benzoic acid derivatives $(0.4 \%)$, phenylpropanoids $(1.4 \%)$, and lignans $(1.2 \%)$ have also been reported. It must be mentioned that the lack of data on the chemical composition of polar fractions and hydroalcoholic and aqueous extracts have direct influence on the number of occurrences of such metabolite groups in literature.

Among the terpenoids, there is a predominance of sesquiterpenes $(65.8 \%)$, which are reported to be present in each species of the subtribe, as shown in Figure 2. Triterpenes $(26.9 \%)$, steroids (2.9\%), saponins $(0.3 \%)$ and monoterpenes $(3.7 \%)$ have also been noted, whereas diterpenes $(0.2 \%)$ were found only in Lychnophora 
Table 1. Chemical constituents isolated and/or identified from species of the subtribe Lychnophorinae*

Species
Eremanthus arboreus (Gardner) MacLeish
[= Vanillosmopsis arborea (Gardner) Baker]
E. argenteus McLeish \& H. Schumacher
E. bicolor (DC.) Baker
E. brasiliensis (Gardner) MacLeish [=Vanil-
losmopsis brasiliensis (Gardner) Sch. Bip.]
E. cinctus Baker

E. crotonoides (DC.) Sch. Bip.

E. elaeagnus (Mart. ex. DC.) Sch. Bip.

E. erythropappus (DC.) MacLeish [Vanillosmopsis erythropappa (DC.) Sch. Bip.]

\section{E. eriopus Sch. Bip. ex Baker \\ E. glomerulatus Less.}

E. goyazensis (Gardner) Sch. Bip.

E. incanus (Less.) Less.

E. mattogrossensis Kuntze

E. mollis Sch. Bip.

E. polhii (Baker) MacLeish [Vanillosmopsis pohlii Baker]

E. seidelii MacLeish \& H. Schmacher

E. uniflorus MacLeish \& H. Schmacher

E. veadeiroensis $\mathrm{H}$. Rob.

Lychnophora affinis Gardner

L. antillana Urb.

L. bahiensis Mattf.

L. blanchetti Sch. Bip.

L. brunioides Mart.

L. columnaris Mattf.

L. crispa Mattf.

$\begin{array}{lcl}\text { Chemical constituents } & \text { Ref. }\end{array}$

$19^{\text {w-EO }}, 25^{\text {w-EO }}, 27^{\text {w-EO/w-Hex }}, 28^{\text {w-Hex }}, 37^{\text {w-EO }}, 39^{\text {w-EO }}, 40^{\text {w-EO }}, 75^{\text {w-EO }}, 77^{\text {w-EO }}, 80^{\text {w-EO }}, 126^{\text {ap-EtOAc }}$, $127^{\text {ap-EtOAc }}, 137^{\text {ap-EtOAc }}, 235^{\text {w-EO }}, 236^{\text {w-EtOH }}, 237^{\text {w-EtOH }}, 266^{\text {ap-EtOAc }}$

$94^{\text {ils- } \mathrm{CHCl}_{3}}, 96^{\mathrm{ils}-\mathrm{CHCl}_{3}}, 135^{\text {ils- } \mathrm{CHCl}_{3}}, 136^{\mathrm{ils}-\mathrm{CHCl}_{3}}, 276^{\text {ils- } \mathrm{CHCl}_{3}}, 291^{\text {ils- }-\mathrm{CHCl}_{3}}, 296^{\text {ils- }-\mathrm{CHCl}_{3}}$

46

83 ap-PE $, 88^{\text {ap-PE}}, 102^{\text {ap-PE }}, 104^{\text {ap-PE }}, 116^{\text {ap-PE }}, 119^{\text {ap-PE }}, 121^{\text {ap-PE }}, 139^{\text {ap-PE}}, 141^{\text {ap-PE }}, 146^{\text {ap-PE }}, 147^{\text {r-PE }}$,

$179^{\mathrm{r}-\mathrm{PE}}, 184^{\mathrm{r}-\mathrm{PE}}, 185^{\mathrm{r}-\mathrm{PE}}, 186^{\mathrm{r}-\mathrm{PE}}, 202^{\mathrm{ap}-\mathrm{PE}}, 203^{\mathrm{r}-\mathrm{PE} / \mathrm{ap}-\mathrm{PE}}, 225^{\mathrm{r}-\mathrm{PE}}, 229^{\mathrm{r}-\mathrm{PE}}, 230^{\mathrm{r}-\mathrm{PE}}, 231^{\mathrm{r}-\mathrm{PE}}$

$34^{\text {ap-PE}}, 69^{\text {ap-PE }}, 84^{\text {ap-PE }}, 113^{\text {ap-PE }}, 179^{\text {ap-PE }}, 201^{\text {ap-PE }}, 202^{\text {ap-PE }}, 203^{\text {ap-PE }}, 230^{\text {ap-PE }}, 231^{\text {ap-PE }}, 289^{\text {ap-PE }}$

8

$190^{\mathrm{i}-\mathrm{CHCl}_{3}}, 203^{\mathrm{is}-\mathrm{CHCl}_{3}}, 216^{\mathrm{is}-\mathrm{CHCl}_{3}}, 219^{\mathrm{is-}-\mathrm{CHCl}_{3}}, 221^{\mathrm{is}-\mathrm{CHCl}_{3}}, 224^{\mathrm{is}-\mathrm{CHCl}_{3}}, 226^{\mathrm{es}-\mathrm{CHCl}_{3}}, 234^{\mathrm{l}-\mathrm{MeOH}}, 257^{\mathrm{i}-\mathrm{MeOH}}$, $272^{\mathrm{es}-\mathrm{MeOH}}, 319^{1-\mathrm{MeOH} / \mathrm{i}-\mathrm{MeOH}}$

$34^{\text {ap-PE }}, 45^{\text {ap-PE }}, 52^{\text {ap-PE}}, 69^{\text {ap-PE }}, 83^{\text {ap-PE }}, 86^{\text {ap-PE }}, 88^{\text {ap-PE }}, 91^{\text {ap-PE }}, 104^{\text {ap-PE }}, 105^{\text {ap-PE }}, 116^{\text {ap-PE }}, 119^{\text {ap-PE }}$, $121^{\text {ap-PE }}, 135^{\text {ap-PE }}, 200^{\text {ap-PE }}, 202^{\text {ap-PE }}, 203^{\text {ap-PE }}, 215^{\text {ap-PE }}, 216^{\text {ap-PE }}$

$27^{\mathrm{l}-\mathrm{MeOH}}, 83^{\mathrm{l}-\mathrm{MeOH}}, 84^{\mathrm{l}-\mathrm{MeOH}}, 101^{1-\mathrm{MeOH}}, 102^{1-\mathrm{MeOH}}, 106^{1-\mathrm{MeOH}}, 107^{1-\mathrm{MeOH}}, 116^{\mathrm{l}-\mathrm{MeOH} / \mathrm{s}-\mathrm{MeOH}: \mathrm{H} \mathrm{O}^{2}}$,

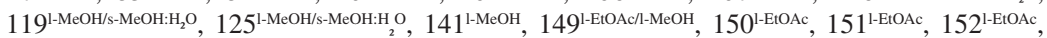
$179^{\text {w-Hex/ap-DCM }}, 199^{\text {s-PE }}, 202^{\text {s-PE }}, 203^{\text {s-PE }}, 215^{\text {l-MeOH }}, 220^{\text {l-MeOH }}, 223^{\text {l-MeOH}}, 224^{1-\mathrm{MeOH}}, 226^{\text {s-PE }}, 227^{\text {s-PE }}$,

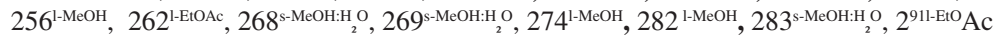

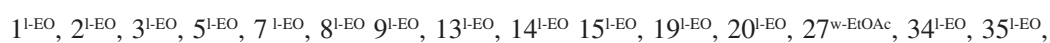
$36^{\text {l-EO }}, 37^{\text {l-EO }}, 38^{\text {l-EO }}, 42^{\text {l-EO }}, 45^{\text {l-EO }}, 52^{\text {1-EO }}, 58^{\text {l-EO }}, 69^{\text {l-EO }}, 71^{\text {l-EO }}, 73^{\text {l-EO }}, 76^{1 \text {-EO }}, 79^{1-\mathrm{EO}}, 83^{\text {ap-Hex/w-EtOAc }}$, $84^{\text {w-EtOAc }}, 91^{\text {w-EtOAc }}, 95^{\text {w-EtOH }}, 136^{\text {w-EtOH }}, 139^{\text {w-EtOH }}, 143^{\text {w-EtOH }}, 147^{\text {w-EtOAc }}, 173^{\text {w-EtOH }}, 174^{\text {w-EtOH }}$, $175^{\mathrm{w}-\mathrm{EtOH}}, 176^{\mathrm{w}-\mathrm{EtOH}}, 177^{\mathrm{w}-\mathrm{EtOH}}, 178^{\mathrm{w}-\mathrm{EtOH}}, 179^{\mathrm{w}-\mathrm{EtOH}}, 180^{\mathrm{w}-\mathrm{EtOH}}, 182^{\mathrm{w}-\mathrm{EtOH}}, 184^{\mathrm{w}-\mathrm{EtOH}}, 191^{\mathrm{w}-\mathrm{EtOH}}$, $193^{\mathrm{w}-\mathrm{EtOH}}, 195^{\mathrm{w}-\mathrm{EtOH}}, 196^{\mathrm{w}-\mathrm{EtOH}}$

$92^{\mathrm{ap}-\mathrm{CHCl}_{3}}, 161^{\mathrm{ap}-\mathrm{CHCl}_{3}}, 272^{\mathrm{ap}-\mathrm{CHCl}_{3}}, 295^{\mathrm{ap}-\mathrm{CHCl}}$

$34^{\text {ap-PE }}, 40^{\text {ap-PE }}, 52^{\text {ap-PE }}, 69^{\text {ap-PE }}, 70^{\text {ap-PE }}, 89^{\text {ap-PE }}, 94^{\text {ap-PE }}, 95^{\text {ap-PE }}, 98^{\text {ap-PE }}, 111^{\text {ap-PE }}, 116^{\text {r-PE/t-Hex:EtOAc }}$, $117^{\text {t-Hex:EtOAc }}, 122^{\text {ap-PE }}, 123^{\text {ap-PE }}, 124^{\text {ap-PE }}, 128^{\text {t-Hex:EtOAc }}, 129^{\text {t-Hex:EtOAc }}, 131^{\text {t-Hex:EtOAc }}, 132^{\text {t-Hex:EtOAc }}$, $134^{\text {t-Hex:EtOAc }}, 135^{\text {ap-PE }}, 147^{\text {r-PE }}, 155^{\text {ap-PE }}, 161^{\text {ap-PE/t-Hex:EtOAc }}, 163^{\text {ap-PE/t-Hex:EtOAc }}, 164^{\text {ap-PE }}, 165^{\text {t-Hex:EtOAc }}$, $191^{\text {ap-PE }}, 200^{r-P E}, 202^{\text {ap-PE }}, 203^{\text {ap-PE/r-PE }}, 204^{\text {ap-PE }}, 209^{\text {r-PE }}, 212^{\text {r-PE }}, 231^{\text {ap-PE }}, 293^{\text {ap-PE }}$

$84^{\text {ap-EtOAc/ap-CHCl }}, 106^{\text {ap-EtOAc }}, 107^{\text {ap-EtOAc }}, 116^{\text {ap-EtOAc }}, 117^{\text {ap-EtOAc }}, 139^{\text {ap-EtOAc }}, 142^{\text {ap-EtOAc }}, 182^{\text {w-EtOH }}$, $183^{\text {w-EtOH }}, 282^{\text {ap-EtOAc }}$

$27^{\text {ap-PE }}, 119^{\text {ap-PE }}, 147^{\text {ap-PE }}, 179^{\text {ap-PE}}, 189^{\text {ap-PE }}, 202^{\text {ap-PE }}, 203^{\text {ap-PE }}, 242^{\text {ap-PE }}$

$24,50-52$

53,54

$84^{\mathrm{ap}-\mathrm{CHCl}_{3}}, 113^{\mathrm{ap}-\mathrm{CHCl}_{3}}, 302^{\mathrm{ap}-\mathrm{CHCl}_{3}}$

$34^{\text {ap-PE }}, 52^{\text {ap-PE }}, 69^{\text {ap-PE }}, 74^{\text {ap-PE }}, 84^{\text {ap-PE }}, 92^{\text {ap-PE }}, 202^{\text {ap-PE }}, 203^{\text {ap-PE/r-PE }}, 239^{\text {ap-PE }}, 243^{\text {ap-PE }}, 244^{\text {ap-PE }}$, $289^{\text {ap-PE }}, 293^{\text {ap-PE }}$

$3^{\text {l-EO }}, 5^{\text {l-EO }}, 13^{\text {l-EO }}, 15^{\text {l-EO }}, 19^{\text {w-EO }}, 27^{\text {w-EO }}, 34^{\text {ap-PE }}, 35^{\text {l-EO }}, 36^{\text {l-EO }}, 45^{\text {w-EO/l-EO }}, 52^{\text {l-EO }}, 69^{\text {ap-PE }}, 73^{\text {l-EO }}$, $84^{\text {ap-PE }}, 113^{\text {ap-PE }}, 202^{\text {ap-PE }}, 203^{\text {ap-PE }}, 204^{\text {ap-PE }}, 212^{\text {ap-PE }}, 214^{\text {ap-PE }}, 215^{\text {ap-PE }}, 216^{\text {ap-PE }}, 230^{\text {ap-PE }}, 231^{\text {ap-PE }}$

$102^{\text {ap-EtOAc }}, 105^{\text {ap-EtOAc }}, 106^{\text {ap-EtOAc }}, 107^{\text {ap-EtOAc/-EtOH }}, 139^{\text {ap-EtOAc }}, 141^{\text {ap-EtOAc }}, 142^{\text {ap-EtOAc }}, 282^{\text {ap-EtOAc }}$

$84^{\mathrm{t}-\mathrm{CHCl}_{3}}, 200^{\mathrm{t}-\mathrm{CH}_{3}}, 202^{\mathrm{t}-\mathrm{CHCl}_{3}}, 203^{\mathrm{t}-\mathrm{CHCl}_{3}}, 205^{\mathrm{t}-\mathrm{CHCl}_{3}} 215^{\mathrm{t}-\mathrm{CHCl}_{3}}, 216^{\mathrm{t}-\mathrm{CHCl}_{3}}, 218^{\mathrm{t}-\mathrm{CHCl}_{3}}, 219^{\mathrm{t}-\mathrm{CHCl}_{3}}, 220^{\mathrm{t}-\mathrm{CHCl}_{3}}$, $221^{\mathrm{t}-\mathrm{CHCl}_{3}}, 224^{\mathrm{t}-\mathrm{CHCl}_{3}}, 233^{\mathrm{t}-\mathrm{CHCl}_{3}}, 234^{\mathrm{t}-\mathrm{CHCl}_{3}}, 240^{\mathrm{t}-\mathrm{CHCl}_{3}}, 262^{\mathrm{t}-\mathrm{MeOH}}, 264^{\mathrm{t}-\mathrm{CHCl}_{3}}, 272^{\mathrm{t}-\mathrm{CHCl}_{3}}, 276^{\mathrm{t}-\mathrm{CHCl}_{3}}, 289^{\mathrm{t}-\mathrm{CHCl}_{3}}$,

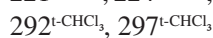

$56^{\mathrm{ap}-\mathrm{CHCl}_{3}}, 179^{\text {s-Hex:EtOAc }}, 192^{\text {s-Hex:EtOAc }}, 200^{\text {s-Hex:EtOAc/s-EtOH }}, 202^{\text {s-EtOH }}, 205^{\text {s-Hex:EtOAc }}, 206^{\text {s-Hex:EtOAc }}$,

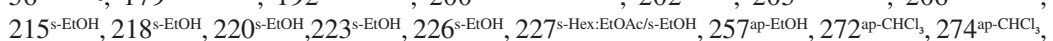
$276^{\text {ap- }-\mathrm{CHCl}_{3} / \mathrm{ap}-\mathrm{EtOH}}, 319^{\text {ap- } \mathrm{CHCl}_{3} / \mathrm{ap}-\mathrm{EtOH}}$

$46^{\text {ap-ЕtОH }}, 47^{\text {ap-ЁОН }}, 90^{\text {ap-ЕtOH }}, 92^{\text {ар-ЕเОH }}, 116^{\text {ap-ЕtOH }}, 121^{\text {ap-ЕtOH }}, 129^{\text {ap-ЕtOH }}, 130^{\text {ap-ЕtOH }}, 132^{\text {ap-ЕtOH }}$, $133^{\text {ap-EtOH }}, 217^{\text {ap-EtOH }}, 271^{\text {ap-EtOH }}, 273^{\text {ap-EtOH }}, 274^{\text {ap-EtOH }}, 275^{\text {ap-EtOH }}, 276^{\text {ap-EtOH }}, 277^{\text {ap-EtOH }}, 294^{\text {ap-EtOH }}$, $297^{\text {ap-EtOH }}, 298^{\text {ap-EtOH }}$

$153^{\text {sl-DCM-MeOH }}, 154^{\text {sl-DCM-MeOH }}, 205^{\text {sl-DCM-MeOH }}, 222^{\text {sl-DCM-MeOH }}$

$83^{\text {r-PE/ap-PE}}, 91^{\text {ap-PE/r-PE }}, 92^{\text {ap-PE }}, 128^{\text {ap-PE}}, 131^{\text {ap-PE }}, 134^{\text {ap-PE }}, 179^{\text {r-PE}}, 184^{\text {r-PE }}, 200^{\text {ap-PE}}, 202^{\text {ap-PE-r-PE }}$, $203^{\text {r-PE/ap-PE }}, 204^{\text {r-PE/ap-PE }}, 230^{\text {r-PE/ap-PE }}$

$41^{\mathrm{r}-\mathrm{PE}}, 71^{\mathrm{r}-\mathrm{PE}}, 83^{\text {ap-PE }}, 91^{\mathrm{r}-\mathrm{PE}}, 147^{\mathrm{r}-\mathrm{PE}}, 148^{\mathrm{r}-\mathrm{PE}}, 157^{\text {ap-PE }}, 158^{\text {ap-PE }}, 159^{\text {ap-PE }}, 160^{\text {ap-PE }}, 162^{\text {ap-PE }}, 165^{\text {ap-PE }}$, $179^{\mathrm{r}-\mathrm{PE} / \mathrm{ap}-\mathrm{PE}}, 188^{\mathrm{r}-\mathrm{PE}}, 190^{\mathrm{r}-\mathrm{PE}}, 193^{\mathrm{r}-\mathrm{PE}}, 202^{\mathrm{ap}-\mathrm{PE}}, 203^{\mathrm{r}-\mathrm{PE}}, 230^{\mathrm{r}-\mathrm{PE} / \mathrm{ap}-\mathrm{PE}}, 242^{\mathrm{r}-\mathrm{PE}}$

$179^{\text {ap-EtOAc }}, 279^{\text {ap-EtOA }}, 280^{\text {ap-EtOA }}, 301^{\text {ap-EtOAc }}, 305^{\text {ap-EtOAc }}, 311^{\text {ap-EtOAc }}, 312^{\text {ap-EtOAc }}, 313^{\text {ap-EtOAc }}$

$8,49,50$

56,57

53,58

56

16,60

53,61

48,62

$52^{\text {ap-PE }}, 53^{\text {ap-PE }}, 54^{\text {ap-PE }}, 55^{\text {ap-PE }}, 56^{\text {ap-PE }}, 62^{\text {ap-PE }}, 63^{\text {ap-PE }}, 64^{\text {ap-PE }}, 65^{\text {ap-PE }}, 66^{\text {ap-PE }}, 67^{\text {ap-PE }}, 68^{\text {ap-PE }}, 91^{\text {ap-PE }}$, $179^{\mathrm{ap}-\mathrm{PE}}, 181^{\mathrm{r}-\mathrm{PE}} 183^{\mathrm{r}-\mathrm{PE}}, 200^{\mathrm{ap}-\mathrm{PE}}, 202^{\mathrm{ap}-\mathrm{PE} / \mathrm{r}-\mathrm{PE}}, 203^{\mathrm{ap}-\mathrm{PE} / \mathrm{r}-\mathrm{PE}}$

$230^{\mathrm{r}-\mathrm{PE}}, 231^{\mathrm{r}-\mathrm{PE}}$

$88^{\text {ap-PE }}, 91^{\text {ap-PE}}, 108^{\text {ap-PE }}, 110^{\text {ap-PE }}, 128^{\text {ap-PE }}, 131^{\text {ap-PE }}, 145^{\text {ap-PE }}, 179^{\text {r-PE }}, 202^{\text {r-PE/ap-PE }}, 203^{\text {r-PE/ap-PE }}$, $230^{\text {r-PE/ap-PE }}$

$84^{\text {ap-EtOAc }}, 85^{\text {ap-EtOAc }}, 92^{\text {ap-EtOAc }}, 93^{\text {ap-EtOAc }}, 282^{\text {ap-EtOAc }}, 301^{\text {ap-EtOAc }}, 311^{\text {ap-EtOAc }}$ 
Table 1. continuation

\begin{tabular}{|c|c|}
\hline Species & Chemical constituents \\
\hline L. ericoides Mart. & 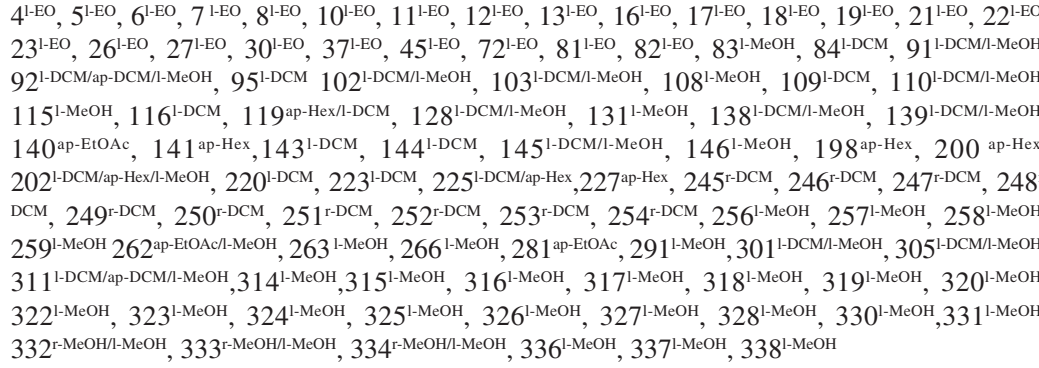 \\
\hline
\end{tabular}

L. granmogolensis (Duarte) D. J. N. Hind

L. hakeaefolia Mart.

L. markgravii Gardner

L. martiana Gardner

L. passerina (Mart. ex DC.) Gardner

L. phylicaefolia DC.

L. pinaster Mart.

L. pohlii Sch. Bip.

L. pseudovillosissima Semir \& Leitão

L. reticulata Gardner

L. rupestris Semir \& Leitão

L. salicifolia Mart.

L. sellowii Sch. Bip.

L. staavioides Mart.

L. trichocarpha (Spreng.) Spreng.

L. uniflora Sch. Bip.

L. villosissima Mart.

Lychnophoriopsis candelabrum (Sch. Bip.) H. Rob.

Minasia alpestris (Gardner) H. Robinson

Piptolepsis ericoides (Less.) Sch. Bip.

P. leptospermoides (Mart. ex DC.) Sch. Bip

P. argentea Mart. \& Zucc. ex Sch. Bip.

P. furnensis Semir \& Leitão Filho $84^{\text {li-EtOAc }}, 90^{\text {li-EtOAc }}, 92^{\text {li-EtOAc }}, 264^{\text {li-EtOAc }}, 270^{\text {li-EtOAc }}, 286^{\text {li-EtOAc }}, 303^{\text {li-EtOAc }}, 304^{\text {li-EtOAc }}, 307^{\text {li-EtOAc }}, 313^{\text {li-EtOAc }}$

$91^{\text {ap/PE}}, 147^{\text {r-PE }}, 179^{\text {r-PE }}, 202^{\text {r-PE/ap-PE }}, 203^{\text {r-PE/ap-PE }}, 229^{\text {r-PE }}, 230^{\text {r-PE }}$

$83^{\mathrm{r}-\mathrm{DCM}}, 88^{\mathrm{r}-\mathrm{DCM}}, 179^{\mathrm{r}-\mathrm{DCM}}, 199^{\mathrm{r}-\mathrm{DCM}}, 200^{\mathrm{r}-\mathrm{DCM}}, 202^{\mathrm{r}-\mathrm{DCM}}, 215^{\mathrm{r}-\mathrm{DCM}}, 218^{\mathrm{r}-\mathrm{DCM}}, 220^{\mathrm{r}-\mathrm{DCM}}, 223^{\mathrm{r}-\mathrm{DCM}}$, $226^{\text {r-DCM }}, 267^{\text {ap-DCM }}, 288^{\text {ap-DCM }}, 301^{\text {ap-DCM }}, 305^{\text {ap-DCM }}, 319^{\text {ap-EtOH }}$

$49^{\text {ap-Hex:EtOAc }}, 51^{\text {ap-Hex:EtOAc }}$

Ref.

$11,12,18$

19,27 ,

68-70

31

13

71

72

$52^{\text {ap-PE }}, 83^{\text {l-EtOH }}, 84^{\text {ap-EtOH/-EtOH/ap-PE }}, 147^{\text {r-PE }}, 179^{\text {r-PE/ap-PE }}, 181^{\text {r-PE }}, 182^{\text {r-PE/ap-PE }}, 183^{\text {r-PE/ap-PE }}, 184^{\text {r-PE/ap-PE }}$, $187^{\mathrm{r}-\mathrm{PE}}, 200^{\mathrm{r}-\mathrm{PE} / \text { ap-PE}}, 202^{\mathrm{r}-\mathrm{PE} / \text { ap-PE}}, 203^{\mathrm{r}-\mathrm{PE} / \text { ap-PE}}, 215^{\mathrm{r}-\mathrm{PE}}, 212^{\mathrm{r}-\mathrm{PE}}, 216^{\mathrm{r}-\mathrm{PE} / \text { ap-PE}}, 217^{\mathrm{ap}-\mathrm{PE}}, 223^{\text {r-PE/ ap-PE }}$ $224^{\mathrm{r}-\mathrm{PE} / \text { ap-PE }}, 257^{\text {1-EtOH }}, 262^{1-\mathrm{EtOH}}, 280^{1 \text {-EtOH }}, 281^{1 \text {-EtOH }}, 319^{\text {l-EtOH }}, 321^{1-\mathrm{MeOH}}$

$45^{\text {ap-PE }}, 179^{\text {r-PE/ap-PE }}, 202^{\text {r-PE/ap-PE }}, 203^{\text {r-PE/ap-PE }}, 210^{\text {ap-PE }}, 229^{\text {r-PE }}, 230^{\text {r-PE }}, 308^{\text {ap-PE }}$,

$46^{\text {ap-Hex }}, 57^{\text {ap-Hex }}, 83^{\text {ap-DCM }}, 202^{\text {ap-Hex }}, 220^{\text {ap-Hex }}, 223^{\text {ap-Hex }}, 227^{\text {ap-Hex }}, 238^{\text {ap-EtOH:H }{ }_{2} \mathrm{O}}, 241^{\text {ap-EtOH:H }{ }_{2} \mathrm{O}}$,

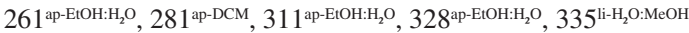

$83^{\mathrm{li}-\mathrm{DCM}}, 84^{\mathrm{li}-\mathrm{DCM}}, 86^{\mathrm{li}-\mathrm{DCM}}, 91^{\mathrm{li}-\mathrm{DCM}}, 92^{\mathrm{li}-\mathrm{DCM} / \mathrm{l}-\mathrm{MeOH}: \mathrm{H}_{2} \mathrm{O}}, 241^{\mathrm{li}-\mathrm{MeOH}}, 258^{\mathrm{li}-\mathrm{MeOH} / \mathrm{l}-\mathrm{MeOH}: \mathrm{H}_{2} \mathrm{O}}, 260^{\mathrm{l}-\mathrm{MeOH}: \mathrm{H}_{2} \mathrm{O}}$, $262^{\mathrm{li}-\mathrm{MeOH}}, 267^{\mathrm{li}-\mathrm{MeOH}}, 269^{\mathrm{li}-\mathrm{H}_{2} \mathrm{O}: \mathrm{MeOH}}, 274^{\mathrm{li}-\mathrm{DCM}}, 279^{\mathrm{li}-\mathrm{DCM}}, 282^{\mathrm{li}-\mathrm{H}_{2} \mathrm{O} \mathrm{O} \mathrm{MeOH} / \mathrm{-MeOH}: \mathrm{H}_{2} \mathrm{O}}, 288^{\mathrm{li}-\mathrm{DCM}}, 300^{\mathrm{l}-\mathrm{MeOH} \mathrm{H}_{2} \mathrm{O}}$ $301^{\mathrm{li}-\mathrm{H}_{2} \mathrm{O}: \mathrm{MeOH} / \mathrm{l}-\mathrm{MeOH}: \mathrm{H}_{2} \mathrm{O}}, 311^{\mathrm{li}-\mathrm{DCM}}, 314^{\mathrm{li}-\mathrm{DCM}}, 320^{\mathrm{li}-\mathrm{H}_{2} \mathrm{O}: \mathrm{MeOH} / \mathrm{l}-\mathrm{MeOH}: \mathrm{H}_{2} \mathrm{O}}, 322^{\mathrm{l}-\mathrm{MeOH}: \mathrm{H}_{2} \mathrm{O}}, 323^{\mathrm{l}-\mathrm{MeOH}: \mathrm{H}_{2} \mathrm{O}}$, $324^{\mathrm{l}-\mathrm{MeOH}: \mathrm{H}_{2} \mathrm{O}}, 325^{\mathrm{l-MeOH}: \mathrm{H}_{2} \mathrm{O}}, 332^{\mathrm{l}-\mathrm{MeOH}: \mathrm{H}_{2} \mathrm{O}}, 333^{\mathrm{l}-\mathrm{MeOH}: \mathrm{H}_{2} \mathrm{O}}, 335^{\mathrm{li}-\mathrm{H}_{2} \mathrm{O} \mathrm{MeOH}}$

$83^{\text {fl-EtOAc/ap-EtOAc }}, 87^{\text {ap-EtOAc }}, 91^{\text {ap-EtOAc/l-MeOH:H } \mathrm{H}_{2} \mathrm{O}}, 166^{\mathrm{fl-EtOAc}}, 167^{\mathrm{fl}-\mathrm{EtOAc}}, 168^{\mathrm{fl}-\mathrm{EtOAc}}, 169^{\mathrm{fl}-\mathrm{EtOAc}}$,

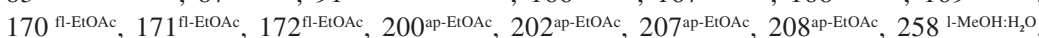
$260^{\mathrm{I}-\mathrm{MeOH}: \mathrm{H}_{2} \mathrm{O}}, 282^{\mathrm{I}-\mathrm{MeOH}: \mathrm{H}_{2} \mathrm{O}}, 300^{\mathrm{l}-\mathrm{MeOH}: \mathrm{H}_{2} \mathrm{O}}, 319^{\mathrm{l}-\mathrm{MeOH}: \mathrm{H}_{2} \mathrm{O}}, 320^{\mathrm{l-MeOH}: \mathrm{H}_{2} \mathrm{O}}, 322^{\mathrm{I}-\mathrm{MeOH}: \mathrm{H}_{2} \mathrm{O}}, 323^{\mathrm{l}-\mathrm{MeOH}: \mathrm{H}_{2} \mathrm{O}}$, $324^{\mathrm{l}-\mathrm{MeOH}: \mathrm{H}_{2} \mathrm{O}}, 325^{1-\mathrm{MeOH}: \mathrm{H}_{2} \mathrm{O}}, 332^{1-\mathrm{MeOH}: \mathrm{H}_{2} \mathrm{O}}, 333^{\mathrm{I}-\mathrm{MeOH}: \mathrm{H}_{2} \mathrm{O}}$

$83^{1-\mathrm{MeOH}}, 202^{\mathrm{l}-\mathrm{MeOH}}, 203^{1-\mathrm{MeOH}}, 204^{\mathrm{l}-\mathrm{MeOH}}, 215^{1-\mathrm{MeOH}}, 216^{1-\mathrm{MeOH}}, 219^{1-\mathrm{MeOH}}, 221^{1-\mathrm{MeOH}}, 223^{\mathrm{l}-\mathrm{MeOH}}$ $224^{\mathrm{l}-\mathrm{MeOH}}, 226^{\mathrm{l}-\mathrm{MeOH}}, 227^{\mathrm{l}-\mathrm{MeOH}}, 302^{1-\mathrm{MeOH}}, 305^{\mathrm{I-MeOH}}$

$91^{\text {li-AcOET }}, 116^{\text {li-EtOAc }}, 117^{\text {li-EtOAc }}, 118^{\text {li-EtOAc }}, 128^{\text {li-EtOAc }}, 131^{\text {li-EtOAc }}, 179^{\text {s-EtOAc }}, 180^{\text {s-EtOAc }}, 202^{\text {li-HEX }}$, $207^{\mathrm{li}-\mathrm{HEX}}, 208^{\mathrm{li}-\mathrm{HEX}}, 223^{\mathrm{li}-\mathrm{HEX}}, 225^{\mathrm{li}-\mathrm{HEX}}, 265^{\mathrm{li}-\mathrm{EtOH}}, 300^{\mathrm{li}-\mathrm{EtOH}}, 332^{\mathrm{s}-\mathrm{MeOH}}$

$43^{\text {ap-PE }}, 44^{\text {ap-PE }}, 45^{\text {ap-PE }}, 46^{\text {ap-PE }}, 48^{\text {ap-PE }}, 49^{\text {s-EtOH/li-EtOAc/ap-PE }}, 51^{\text {li-EtOAc/ls-EtOH }}, 59^{\text {ap-PE }}, 60^{\text {ap-PE }}, 61^{\text {ap-PE }}, 147^{\text {ap-PE }}$, $179^{\text {r-PE/ap-PE }}, 202^{\text {ls-EtOH/ap-PE/li-EtOAc }}, 203^{\text {r-PE/ap-PE }}, 212^{\text {r-PE }}, 216^{\text {r-PE }}, 223^{\text {ap-PE }}, 224^{\text {ap-PE/r-PE }}, 230^{\text {r-PE/ap-PE }}$, $231^{\text {ap-PE/r-PE }}, 276^{\text {li-EtOAc }}, 287^{\text {li-EtOAc }}, 297^{\text {li-EtOAc }}$

$31^{\text {ap-PE }}, 32^{\text {ap-PE }}, 33^{\text {ap-PE }}, 91^{\text {ap-PE }}, 92^{\text {ap-PE }}, 114^{\text {ap-PE }}, 115^{\text {ap-PE }}, 179^{\text {ap-PE }}, 197^{\text {ap-PE }}, 202^{\text {ap-PE }}, 203^{\text {ap-PE }}, 230^{\text {ap-PE }}$ $255^{\mathrm{l}-\mathrm{MeOH}}, 258^{\mathrm{l}-\mathrm{MeOH}}, 264^{\mathrm{l}-\mathrm{MeOH}}, 267^{\mathrm{l}-\mathrm{MeOH}}, 288^{1-\mathrm{MeOH}}, 291^{1-\mathrm{MeOH}}, 301^{1-\mathrm{MeOH}}, 305^{\mathrm{l}-\mathrm{MeOH}}, 311^{1-\mathrm{MeOH}}$, $314^{\mathrm{I}-\mathrm{MeOH}}, 332^{\mathrm{s}-\mathrm{MeOH}}$

$91^{\text {ap-EtOH }}, 116^{\text {ap-EtOH }}, 199^{\text {ap-EtOH }}, 200^{\text {ap-EtOH }}, 202^{\text {ap-EtOH }}, 220^{\text {ap-EtOH }}, 223^{\text {ap-EtOH }}, 227^{\text {ap-EtOH }}$

$59^{\text {ap-PE }}, 91^{\text {ap-PE/r-PE }}, 116^{\text {ap-PE }}, 128^{\text {ap-PE }}, 179^{\text {r-PE }}, 200^{\text {ap-PE }}, 202^{\text {ap-PE/r-PE }}, 203^{\text {ap-PE/r-PE }}, 204^{\text {ap-PE/r-PE }}, 208^{\text {ap-PE }}$ $210^{\text {ap-PE }}, 212^{\text {ap-PE/r-PE }}, 216^{\text {ap-PE }}, 223^{\text {ap-PE }}, 224^{\text {ap-PE }}$

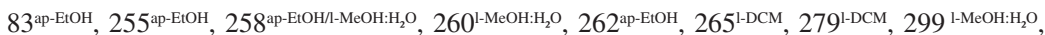

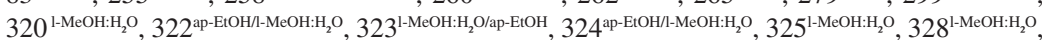
$332^{\text {ap-EtOH }}, 333^{\text {ap-EtOH/l-MeOH: } \mathrm{H}_{2} \mathrm{O}}$

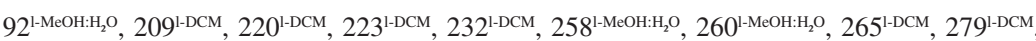

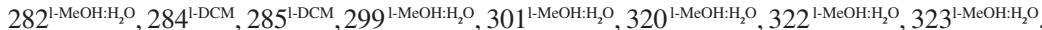
$324^{\mathrm{l}-\mathrm{MeOH}: \mathrm{H}_{2} \mathrm{O}}, 325^{\mathrm{I}-\mathrm{MeOH}: \mathrm{H}_{2} \mathrm{O}}, 327^{\mathrm{l}-\mathrm{MeOH}: \mathrm{H}_{2} \mathrm{O}}, 328^{\mathrm{I}-\mathrm{MeOH}: \mathrm{H}_{2} \mathrm{O}}, 333^{\mathrm{l}-\mathrm{MeOH}: \mathrm{H}_{2} \mathrm{O}}$

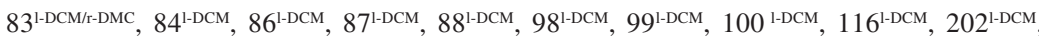
$215^{\text {I-DCM }}, 218^{\text {I-DCM }}, 220^{1-D C M}, 221^{1-D C M}$

$110^{\mathrm{r}-\mathrm{PE}}, 164^{\mathrm{r}-\mathrm{PE}}, 202^{\mathrm{r}-\mathrm{PE}}, 203^{\text {r-PE }}, 204^{\mathrm{ap}-\mathrm{PE} / \mathrm{r}-\mathrm{PE}}, 229^{\mathrm{ap}-\mathrm{PE} / \mathrm{r}-\mathrm{PE}}, 230^{\mathrm{r}-\mathrm{PE}}$

4, 17,37

37,73

$28,70,74$

$28,68,70$

76,77

$13,14,32$,

78,79

21

39,77

80,81

14

$28,70,82$

15,28

16

$24^{\text {ap-PE}}, 34^{\text {ap-PE}}, 52^{\text {ap-PE}}, 91^{\text {ap-PE}}, 97^{\text {ap-PE}}, 116^{\text {ap-PE }}, 117^{\text {ap-PE }}, 128^{\text {ap-PE }}, 156^{\text {ap-PE }}, 179^{r-P E}, 201^{\text {ap-PE }}$, $203^{\text {ap-PE/r-PE }}, 204^{\text {ap-PE/r-PE }}, 216^{\text {r-PE }}, 217^{\text {r-PE }}, 229^{\text {ap-pe }}$

$91^{\text {ap-PE/r-PE }}, 94^{\text {ap-PE/r-PE }}, 128^{\text {ap-PE/r-PE }}, 135^{\text {ap-PE/r-PE }}, 202^{\text {ap-PE/r-PE }}, 203^{\text {ap-PE/r-PE }}, 204^{\text {ap-PE }}, 212^{\text {ap-PE/r-PE }}, 214^{\text {r-PE }}$ $229^{\mathrm{r}-\mathrm{PE}}, 230^{\mathrm{ap}-\mathrm{PE} / \mathrm{r}-\mathrm{PE}}, 231^{\mathrm{ap}-\mathrm{PE} / \mathrm{r}-\mathrm{PE}}$

$91^{\text {ap-EtOAc }}, 82^{\text {ap-EtOAc }}$

* The superscripts following the number of the compound indicates the part of the plant and the extract from which each compound was isolated. w: wood; ap: aerial parts; r: roots; i: inflorescences; is: internal part of stem; es: external part of stem; l: leaves; t: total plant; li: leaves and inflorescences; EO: essential oil; Hex: hexane; EtOAc: ethyl acetate; PE: petroleum ether; DCM: dichloromethane; EtOH: ethanol; MeOH: methanol. 


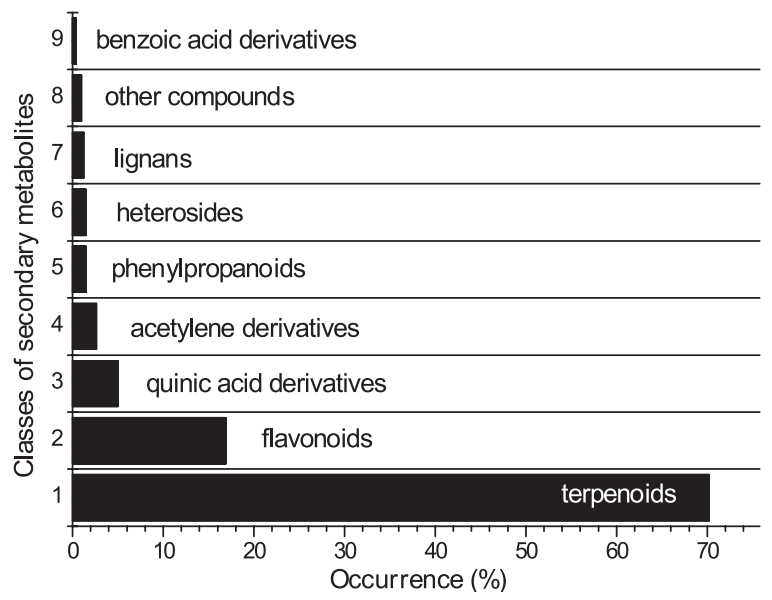

Figure 1. Percentage of secondary metabolites occurrence in Lychnophorinae (percentage was calculated in relation to the total hit number)

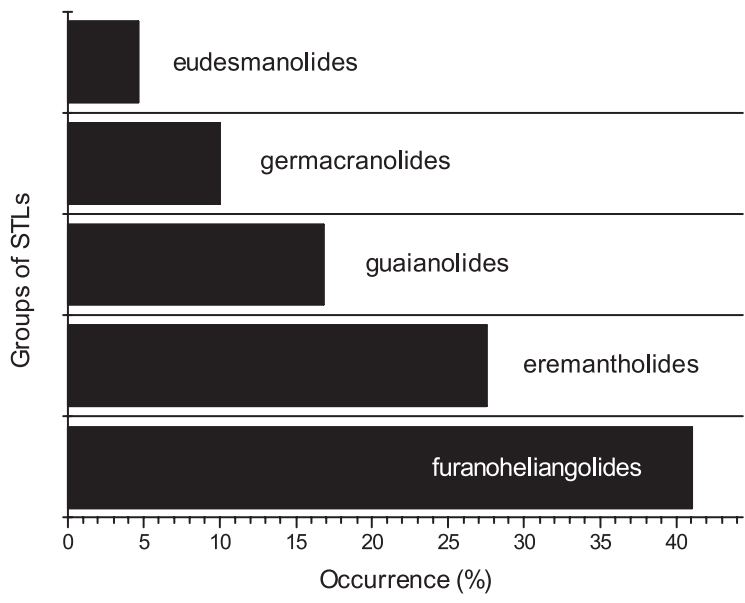

Figure 2. Occurrence of sesquiterpene lactones (SLTS) in Lychnophorinae (percentage was calculated in relation to the total hit number)

selowii. ${ }^{21}$ Regarding the sesquiterpenes, sesquiterpene lactones (STL) are reported to be isolated and/or identified in $90 \%$ of the species investigated. This class of secondary metabolites is divided into groups (i.e., germacranolides, eudesmanolides, guaianolides, furanoheliangolides, among others) according to their structural diversity, which results of enzyme-catalyzed and eventually selective oxidations, cyclizations, condensations and rearrangements of their common biosynthetic precursor (farnesylpyrophosphate, FPP). ${ }^{22}$ Because of their number of occurrence and structural diversity, STLs have been used as chemotaxonomic markers of various taxa of Asteraceae, ${ }^{23}$ including the subtribe Lychnophorinae., ${ }^{4,22}$

Furanoheliangolides from the goyazensolide and eremantholide types are the most common STLs in Lychnophorinae, as shown in Figure 3. They have been reported to be the major STL of all the investigated species, except for Lychnophoriopsis candelabrum, Lychnophora pseudovillosissima and L. reticulata, in which the predominance of guaianolides and eudesmanolides were observed. Furanoheliangolides of the eremantholide type has been proposed to be biosynthesized from a goyazensolide type of STL by means of a Michael-type addition to the exocyclic double bond conjugated with the lactone carbonyl (Figure 3). ${ }^{22,24}$ The conversion of goyazensolidetype into eremantholide in laboratory was recently achieved by making use of Striker's reagent. ${ }^{25}$ Most of the furanoheliangolides from goyazensolide type occurring in Lychnophorinae have the same structural core, but they differ on the degree of oxidation and substituents at C-8. The majority mostly exhibit exocyclic double bond between $\mathrm{C}-11$ and $\mathrm{C}-13$ (94.8\%) and an oxygenated group (a hydroxyl or an acyloxy group) bounded at C-8 (100\%), followed by common methacryloxy (52.2\%), angeloxy (36.5\%), tigloxy $(11.3 \%)$ or their derivatives. In contrast, oxygenated groups at C-15 (26.9\%) and double bonds between C-4 and C-5 (74.8\%) are less common. The oxygenated groups at C-8 from mostly of the STL of Lychnophorinae are usually $\alpha$-orientated in relation to the mean plane of the ring, as reported for other subtribes of Vernonieae. ${ }^{22}$ Differently, the furanoheliangolides of the eremantholide type mostly shows double bond between C-4 and C-5 (72.7\%) and hydroxyl at C-1' (93.5\%), whereas oxygenated groups at $\mathrm{C}-15$ are rarely found (20.8\%).

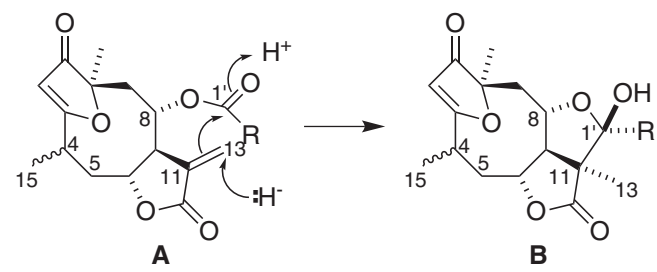

Figure 3. Biogenesis of eremantholides (B) from goyazensolide-type of furanoheliangolides $(\boldsymbol{A})^{24}$

Flavonoids also have a widespread occurrence in the subtribe Lychnophorinae. Flavonols (37.4\%) and flavones (38.7\%) have higher percentages of occurrence than dihydroflavones (12.9\%), dihydroflavonols (9.7\%) and chalcones (1.3\%). Methoxyl (53.3\%) and glycosyl $(25.0 \%)$ are the most common substituent groups in flavones. The glycosyl groups are often bounded at C-6 and C-8 or at C-8 solely. In the case of flavonols, only $37.9 \%$ exhibit free hydroxyl group at C-3 (B ring), once this group is the precursor of methoxyl (32.8\%), glycosyl (8.6\%) and heteroside groups (20.7\%). Chalcones have been identified only in Lychnophora ericoides. ${ }^{26}$

Opposed to terpenoids and flavonoids, whose occurrence is widespread in Lychnophorinae, some classes of secondary metabolites have been restricted to some species. Lignans were isolated only from roots of Lychnophora ericoides, ${ }^{11}$ and quinic acid derivatives have been found only in some Lychnophora species (L. ericoides, ${ }^{12,27}$ L. pinaster, ${ }^{28}$ L. pohli ${ }^{28}$ and L. vilosissima ${ }^{28}$ ) and Lychnophoriopsis candelabrum. ${ }^{28}$

\section{BIOLOGICAL ACTIVITIES OF LYCHNOPHORINAE}

Although fifty species of Lychnophorinae have been submitted to phytochemical studies, up to now only twenty-eight species were investigated regarding their biological activities, as shown in Table 2. Several biological activities from the species of the Lychnophorinae subtribe have been evaluated, and their mostly common reported activities are antimicrobial, anti-inflammatory, tripanocidal, toxicity, analgesic and antinociceptive (Figure 4).

Extracts from the Lychnophora species have been used in the Brazilian folk medicine as analgesic and anti-inflammatory. For this reason, a number of studies have focused on the evaluation of crude extracts and pure compounds for their analgesic and antiinflammatory potential. Guzzo and co-workers ${ }^{29}$ investigated the antinociceptive activity of the ethanol aerial parts extracts of five Lychnophora species using hot-plate and writhing tests. They reported that the Lychnophora pinaster $(0.75 \mathrm{~g} / \mathrm{kg})$ and Lychnophora ericoides $(1.50 \mathrm{~g} / \mathrm{kg})$ extracts significantly increased the time for paw licking in mice. By using the dose of $0.75 \mathrm{~g} / \mathrm{kg}$ for Lychnophora passerina, Lychnophoriopsis candelabrum and Lychnophora pinaster, and doses of 0.75 and $1.50 \mathrm{~g} / \mathrm{kg}$ for both Lychnophora ericoides and Lychnophora trichocarpha it was observed a significant reduction on the number 
Table 2. Biological activities of species of the subtribe Lychnophorinae

\begin{tabular}{|c|c|c|}
\hline Species & Tested biological activities & Ref. \\
\hline \multirow[t]{3}{*}{ Eremanthus arboreus } & Antiinflammatory activity of 15-hydroxyeremantholide B (126) and 15-acetoxyeremantholide B (127) & 87 \\
\hline & Gastroprotective effect of the bark essential oil & 88 \\
\hline & Anticholinesterase activity of dichloromethane:methanol and dichloromethane extracts & 89 \\
\hline \multirow[t]{7}{*}{ E. elaeagnus } & Antitumoral activity of the ethanolic extract from stems and eremantholide A (119) & 24,52 \\
\hline & Antiinflammatory activity of 15 -deoxygoyazensolide (83) & 87 \\
\hline & Citotoxicity of lychnopholide (91) & 90 \\
\hline & Clastogenicity of eremanthin (179) and lychnopholide (91) & 90,91 \\
\hline & Genotoxicity of eremanthin (179) & 91 \\
\hline & Immunomodulatory activity of eremanthin (179) & 92 \\
\hline & $\begin{array}{l}\text { Schistossomicidal activity of eremanthin (179), costunolide (147) and } \alpha \text {-bisabolol (27) against Schis- } \\
\text { tosoma mansoni }\end{array}$ & 92,93 \\
\hline \multirow[t]{7}{*}{ E. erythropappus } & Antimicrobial activity of the essential oil of leaves and $\beta$-bisabolene (25) & $35,45,94$ \\
\hline & Toxicity of extracts and essential oil of leaves & 44,45 \\
\hline & Antifungal activity of essential oil, extracts and $\alpha$-bisabolol (27) & 95,96 \\
\hline & Moluscidal activity of the aerial parts ethanol extract against Biomphalaria glabrata & 97 \\
\hline & Antiedematogenic activity of the essential oil of leaves & 98 \\
\hline & Antinociceptive and antiinflammatory activities of the essential oil of leaves & $36,95,99$ \\
\hline & Antiulcerogenic activity of the essential oil of leaves and $\alpha$-bisabolol (27) & 100 \\
\hline E. glomerulatus & Moluscidal activity of the aerial parts ethanol extract against Biomphalaria glabrata & 57,97 \\
\hline E. goyazensis & Citotoxicity and schistossomicidal activity of goyazensolide (84) against Schistosoma mansoni & 101 \\
\hline E. incanus & Cytotoxic activity of eregoyazin (182) & 41 \\
\hline E. mattogrossensis & Antiinflamamatory activity of goyazensolide $(\mathbf{8 4})$ and isogoyazensolide (112) & 87 \\
\hline E. pohlii & Inseticidal activity of the essential oil against Bemisia argentifolii & 60 \\
\hline E. sphaerocephalus & Moluscicidal activity of the ethanol extract from the aerial parts against Biomphalaria glabrata & 97 \\
\hline Lychnophora affinis & $\begin{array}{l}\text { Antineoplastic activity and citotoxicity of flavonoids (255-321), lychnophorolide A (92) and lychno- } \\
\text { pholic acid (46) }\end{array}$ & $9,40,42$ \\
\hline L. antillana & Antineoplastic activity of crude ethanolic extract, lychnostatin $1(\mathbf{1 5 3})$ and $2(\mathbf{1 5 4})$ & 10 \\
\hline L. brunioides & Moluscidal and tripanocidal activity of flavonoids isolated from the ethyl acetate extract of leaves & 65,102 \\
\hline L. diamantinana & Antinociceptive and anticonvulsant effects of stems methanol extracts & 77 \\
\hline \multirow[t]{10}{*}{ L. ericoides } & Analgesic activity of the crude lyophilized aqueous extracts from stem and leaves & 5 \\
\hline & Analgesic activity of di-caffeoyquinic acids $(\mathbf{3 2 5}, \mathbf{3 3 2}$ and $\mathbf{3 3 3})$ isolated from roots methanolic extracts & 12 \\
\hline & $\begin{array}{l}\text { Analgesic and antioxidant activities of di- } C \text {-glucosylflavones isolated from hydromethanolic extract } \\
\text { of leaves }\end{array}$ & 18 \\
\hline & $\begin{array}{l}\text { Anti-inflammatory, antipyretic and antiedematogenic activities of lignans (245-254) isolated from the } \\
\text { dichloromethane extract of roots }\end{array}$ & 11 \\
\hline & In vitro anti-inflammatory activity of centratherin $(\mathbf{9 2})$ and goyazensolide $(\mathbf{8 4})$ & 33 \\
\hline & Antinociceptive and anti-inflammatory activity of ethanol extract from the aerial parts & 29 \\
\hline & Antiproliferative activity of goyazensolide $(\mathbf{8 4})$ isolated from cell culture & 103 \\
\hline & Genotoxicity of 15-deoxygoyazensolide (83) & 43 \\
\hline & Inhibitory activity of flavonoids $264,281,283$ and 303 on generation of reactive oxygen species & 104 \\
\hline & Xantine oxidase inhibitory activity of the ethanolic extract of the aerial parts & 105 \\
\hline L. gardneri & Tripanocidal activity of crude extracts, flavonoids (255-321) and lychnopolic acid (46) & 37 \\
\hline L. granmongolense & $\begin{array}{l}\text { Tripanocidal and analgesic activities of the crude hexane, ethyl acetate and and ethanol extracts from } \\
\text { the aerial parts and centratherin }(\mathbf{9 2}) \text {; goyazensolide }(\mathbf{8 4}) \text {, lychnophorolide B }(\mathbf{9 0}) \text { and the flavonoid } \mathbf{3 0 3}\end{array}$ & 31 \\
\hline \multirow[t]{2}{*}{ L. markgravii } & $\begin{array}{l}\text { Antimicrobial activity of crude extracts from the aerial parts and flavonoids (255-321) against Strep- } \\
\text { tococcus } s p\end{array}$ & 106 \\
\hline & Leishmanicidal activity of flavonoids $\mathbf{2 6 7}$ and $\mathbf{3 0 5}$, against Leishmania amazonensis & 106 \\
\hline \multirow[t]{5}{*}{ L. passerina } & Tripanocidal activity of the hydroalcoholic extract of aerial parts and goyazensolide (84) & 37,107 \\
\hline & Antinoceptive and antiinflammatory activities of the ethanolic extract from the aerial parts & 29 \\
\hline & Inhibitory activity of flavonoids $264,281,283$ and 303 on generation of reactive oxygen species & 104 \\
\hline & $\begin{array}{l}\text { Antioxidant activity of methanolic extracts from leaves, and quercetin (281), kaempferol (280) and } \\
\text { tiliroside (319) }\end{array}$ & 17 \\
\hline & Xantine oxidase inhibitory activity of the ethanolic extract of the aerial parts & 105 \\
\hline \multirow[t]{4}{*}{ L. pinaster } & Antinoceptive and antiinflammatory activities of the ethanolic extract from the aerial parts & 29 \\
\hline & Moluscicidal activity of the ethanolic extract of the aerial parts against Biomphalaria glabrata & 97 \\
\hline & Tripanocidal activity of the aqueous and hexane extracts of the aerial parts and lichnopholic acid (46) & 37,108 \\
\hline & Xantine oxidase inhibitory activity of the ethanolic extract of the aerial parts & 97 \\
\hline
\end{tabular}


Table 2. continuation

\begin{tabular}{|c|c|c|}
\hline Species & Tested biological activities & Ref. \\
\hline \multirow[t]{2}{*}{ L. pohlii } & $\begin{array}{l}\text { Tripanocidal activity of the n-hexane, dichlorometane and methanol extracts of leaves and inflorescentes, } \\
\text { and lychnopholide (91), centratherin }(\mathbf{9 2}) \text {, goyazensolide }(\mathbf{8 4}), 15 \text {-deoxygoyazensolide (83), caffeic acid } \\
\text { (241), luteolin (262) and vicenin-2 (258) }\end{array}$ & 74 \\
\hline & Inhibitory activity of flavonoids $264,281,283$ and 303 on generation of reactive oxygen species & 104 \\
\hline L. pseudovilosissima & Moluscicidal activity of the ethanol extract from the aerial parts against Biomphalaria glabrata & 97 \\
\hline L. rupestris & Antinociceptive and anticonvulsant effects of polar extracts and 4,5-di-O-[E]-caffeoylquinic acid (331) & 77 \\
\hline \multirow[t]{3}{*}{ L. salicifolia } & Antifungal activity of crude extract and sesquiterpene lactones & 109 \\
\hline & $\begin{array}{l}\text { Tripanocidal and antinociceptive activity of ethyl acetate extracts from leaves and inflorescences, lych- } \\
\text { nopholic acid (46) and quercetin-7,3', } 4^{\prime} \text {-trimethyl ether }\end{array}$ & 32 \\
\hline & $\begin{array}{l}\text { Antimicrobial activity of lupeol (202), lychnopholic acid (46) and its acetate (51) against Escherichia } \\
\text { coli, Staphylococcus aureus, Candida albicans, C. tropicalis, Tricophyton rubrum, Aspergillus flavus, } \\
\text { Penicillium and Rhodotura rubra }\end{array}$ & 78,109 \\
\hline \multirow[t]{3}{*}{ L. staavioides } & Tripanocidal activity of the flavonoid $\mathbf{2 8 2}$ & 39 \\
\hline & Antinociceptive and anticonvulsant effects of polar extracts and 4,5-di-O- $[E]$-caffeoylquinic acid (332) & 77 \\
\hline & Xantine oxidase inhibitory activity of the ethanolic extract of the aerial parts & 91 \\
\hline \multirow[t]{4}{*}{ L. trichocarpha } & $\begin{array}{l}\text { Tripanocidal activity of the ethanol extract of the aerial parts; lychnopholide (91) and eremantholide } \\
\text { C (116) }\end{array}$ & 37,38 \\
\hline & $\begin{array}{l}\text { Antimicrobial activity of lycnopholide }(\mathbf{9 1}) \text {, eremantholide C }(\mathbf{1 1 6}) \text { and Five synthetic derivatives against } \\
\text { Enterococcus faecalis, Bacilus subtilis, Staphylococcus aureus, Salmonella typhymurium, Escherichia } \\
\text { coli and Proteus } \mathrm{sp}\end{array}$ & 80 \\
\hline & Xantine oxidase inhibitory activity of the aerial parts ethanol extract & 91 \\
\hline & Antinoceptive and antiinflammatory activities of the aerial parts ethanol extract & 29 \\
\hline L. villosissima & Tripanocidal activity of 15-deoxygoyazensolide (83) & 38,82 \\
\hline \multirow[t]{2}{*}{ Lychnophoriopsis candelabrum } & Xantine oxidase inhibitory activity of the aerial parts ethanol extract & 91 \\
\hline & Antinoceptive and antiinflammatory activities of the aerial parts ethanol extract & 29 \\
\hline Proteopsis furnensis & Antiinflamatory activity of centratherin $(\mathbf{9 2})$ & 87 \\
\hline
\end{tabular}

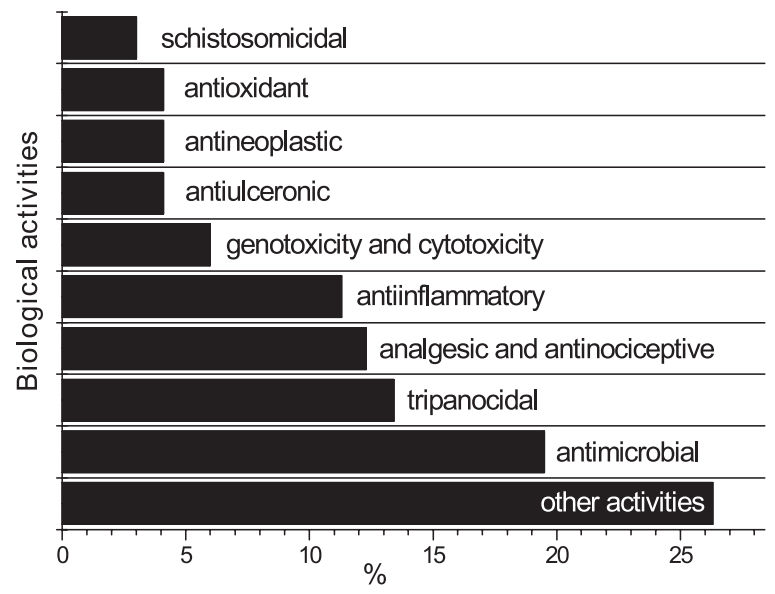

Figure 4. Biological activities of species of the subtribe Lychnopnhorinae reported in the literature. Percentage was calculated in relation to the total number of hits

of writhes induced by acetic acid. This activity was initially proposed due to the presence of sesquiterpene lactones. ${ }^{30}$ However, Grael and co-workers ${ }^{31}$ reported that extracts of the aerial parts of Lychnophora granmongolense showed no analgesic activity in the writhing model of pain, even though the STLs goyazensolide (84) and centratherin (92) were isolated from those extracts. These results, in combination with those obtained for the $L$. salicifolia extracts, ${ }^{32}$ suggested that not all the Lychnophora species could exhibit analgesic activity correlated to the accumulation of sesquiterpene lactones. Differently, lignans ${ }^{11}$ and di-caffeoylquinic acid derivatives, ${ }^{12}$ isolated from roots of Lychnophora ericoides exhibited interesting analgesic activity. More recently, di-caffeoylquinic acid derivatives were also identified in the leaves of L. ericoides, ${ }^{26}$ thus indicating that these compounds can be responsible for the analgesic activity of the hydroalcoholic extracts used by the Brazilian population.

Rungeler and co-workers ${ }^{33}$ investigated the anti-inflammatory activity of 28 sesquiterpene lactones (STL), which are commonly found in leaves and aerial parts of extracts of Lychnophora and other species from the subtribe Lychnophorinae. These compounds are known to inhibit the transcription factor NF- $\kappa \mathrm{B}$ by selectively alkylating its $\mathrm{p} 65$ sub-unit probably by reacting with cysteine residues. ${ }^{30}$ The authors proposed that the $\alpha$-methylene- $\gamma$-lactone and $\alpha, \beta$-unsaturated carbonyl can alkylate the cysteine residue (Cys 38) in the DNA binding loop 1 (L1) and a further cysteine (Cys 120) in the nearby E' region. This cross link alters the position of tyrosine 36 and additional amino acids in such a way that their specific interactions with the DNA become impossible. ${ }^{33}$ However, Gobbo-Neto and co-wokers ${ }^{18}$ recently reported that vicenin-2 (258), isolated from the methanol extract of the leaves of Lychnophora ericoides showed significant anti-inflammatory activity in the carrageenan-induced rat paw edema, thus indicating that this compound is responsible for the anti-inflammatory activity. More recently, Dos Santos and co-workers $^{34}$ demonstrated that vicenin-2 (257) exhibits no effect on tumor necrosis factor (TNF)- $\alpha$ production, but inhibits, in a dose-dependent manner, the production of prostaglandin (PG) E2 without altering the expression of cyclooxygenase (COX)-2 protein. Also, the authors reported that 3,5-dicaffeoylquinic acid (333) and 4,5-dicaffeoylquinic acid (332), at lower concentrations, had small but significant effects on reducing PGE2 levels; at higher doses these compounds stimulated PGE2 and also TNF- $\alpha$ production by the cells. Both compounds $\mathbf{3 3 3}$ and 332, in a dose-dependent manner, were able to inhibit monocyte chemoattractant protein-3 synthesis/ release, with compound $\mathbf{3 3 2}$ being the most potent at the highest tested concentration. These results strongly suggested that the antiinflammatory effect of hydroalcoholic extracts of $L$. ericoides are due to the presence of compounds $\mathbf{3 3 2}$ and $\mathbf{3 3 3}$, rather than sesquiterpene 
lactones. In addition, Guzzo and co-workers ${ }^{29}$ investigated the ethanolic extracts of the aerial parts of five Lychnophora species for their anti-inflammatory and antinociceptive activities. They reported that administration of Lychnophora pinaster and Lychnophora trichocarpha ointments, in both evaluated concentrations (5 and 10\%, w/w), and Lychnophora passerina and Lychnophoriopsis candelabrum, in the concentration of $10 \%$, significantly reduced the paw edema measured $3 \mathrm{~h}$ after carrageenan administration, suggesting, for the first time, an anti-inflammatory activity upon topical administration of these species. However, the authors did not report the chemical composition of those extracts.

Despite the fact that sesquiterpene lactones have a widespread occurrence in the Eremanthus species, most of the biological activities of this genus are due to their essential oils from the leaves and stems. Nascimento and co-workers ${ }^{35}$ investigated the activity of Eremanthus erythropappus oil and some of its compounds and their potential synergistic interaction with ampicillin against different strains of Staphylococcus aureus. They identified $\beta$-bisabolene as the main active constituent and reported its potential to restore the effectiveness of ampicilin against the resistant $S$. aureus.

Recently, the antimicrobial activity of this oil against Candida albicans and Salmonella ssp was also reported, but the major constituents were $\beta$-pinene and $\beta$-caryophyllene instead of $\beta$-bisabolene. ${ }^{6}$ More recently, the essential oil of E. erythropappus was also investigated for its antinociceptive and anti-inflammatory activities. ${ }^{36}$ The authors found that doses of 200 and $400 \mathrm{mg} / \mathrm{kg}$ inhibited $10.69 \%$ and $27.06 \%$ of acetic-acid-induced writhing in mice, respectively. In the formalin-induced nociception test in mice, the essential oil inhibited the first phase of paw licking by $29.13 \%(400 \mathrm{mg} / \mathrm{kg})$ and the second phase by $32.74 \%(200 \mathrm{mg} / \mathrm{kg})$ and $37.55 \%(400$ $\mathrm{mg} / \mathrm{kg}$ ). In the hot-plate test in mice, doses of 200 and $400 \mathrm{mg} / \mathrm{kg}$ significantly increased the reaction time after 30,60 and $90 \mathrm{~min}$ of treatment. Doses of 200 and $400 \mathrm{mg} / \mathrm{kg}$ inhibited carrageenaninduced paw edema in rats by 15.18 and $36.61 \%$, respectively. Doses of 200 and $400 \mathrm{mg} / \mathrm{kg}$ administered $4 \mathrm{~h}$ before intra-pleural injection of carrageenan significantly reduced exudation volume (by 20.20 and $48.70 \%$, respectively) and leucocyte mobilization (by 5.88 and $17.29 \%$, respectively).

The trypanocidal activity of the Lychnophora species has been extensively investigated in the literature. In this case, however, these studies are part of an intensive search for active compounds against Trypanosoma cruzi, the etiology agent of Chaga's disease, therefore, they are not correlated with the use of species from the subtribe Lychnophorinae in traditional medicine. The bioguided fractionation of the crude extracts of $L$. passerina, $L$. pinaster and $L$. trichocarpha resulted in the isolation of the bioactive sesquiterpene lactones goyazensolide (84), eremantholide C (116), lychnopholide (91), and lychnophoic acid (57). ${ }^{37}$ Goyazensolide and eremantholide $\mathrm{C}$ were $100 \%$ active at concentrations of 240 and $3600 \mu \mathrm{g} / \mathrm{mL}$, whereas lychnopholide inhibited $50 \%$ of the grown of trypomastigote forms at concentration of $150 \mu \mathrm{g} / \mathrm{mL} .{ }^{38}$ Besides goyazensolide, centratherin (92) and the flavonoid eridictyol (303), isolated from $L$. granmongolense were also found to be active against T. cruzi. ${ }^{31}$ Quercetin 3-methyl ether (291), isolated from L. staavioides showed also significant trypanocidal activity. ${ }^{39}$

Flavonoids and sesquiterpene lactones have also been investigated for their citotoxicity ${ }^{40-42}$ and genotoxicity. ${ }^{43}$ Recent studies performed by Vasconcellos and co-workers ${ }^{43}$ demonstrated that 15-deoxygoyazensolide (83) is mutagenic in Saccharomyces cerevisae due to the possible intercalation effect, in addition to the pro-oxidant status that exacerbates oxidative DNA damage. Studies on the toxicity of the essential oil of Eremanthus erythropappus have also been reported. ${ }^{44,45}$

\section{CONCLUDING REMARKS}

In this literature review, information concerning the occurrence and pharmacological activities of secondary metabolites isolated from species of the subtribe Lychnophorinae were collected. Sesquiterpene lactones of furanoheliangolide (goyazensolide and eremantholide types) and flavonoids are the distinguished secondary metabolites. Anti-inflammatory, analgesic, antimicrobial and cytotoxic properties are amongst the most investigated activities in the literature, mainly for the Lychnophora and Eremanthus species. However, a number of species of Lychnophorinae has not been submitted to phytochemical or pharmacological studies yet. Furthermore, although vicenin-2 and di-caffeoylquinic acids have been reported responsible for the antiinflammatory and analgesic activities of the hydroalcoholic extracts of Lychnophora ericoides used in the medicine folk, a number of other species of Lychnophorinae used by the Brazilian population for medicinal purposes remains unknown until now. In this context, data presented herein demonstrated not only the role played by species of Lychnophorinae as source of bioactive compounds, but also reinforce the need of further studies involving species of such subtribe.<smiles>C=CC(C)=CCC=C(C)C</smiles>

1<smiles>C=CC(=C)CCC=C(C)C</smiles>

3<smiles>CC1=CCC(C(C)C)=CC1</smiles><smiles>C=C1C=CC(C(C)C)CC1</smiles>

9<smiles>CC1=CCC2(C(C)C)CC1C2</smiles>

12<smiles>CC1=CC2CC3CC1CC23C</smiles>

15<smiles>C=C[C@](C)(O)CCC=C(C)C</smiles>

4<smiles>CC1=CCC(O)(C(C)C)CC1</smiles><smiles>CC(C)C1CC[C@H](C)[C@H](C)C1</smiles><smiles>CC12CC3CC(CC(C3)C1)C2</smiles><smiles>C=C1C2CCC(C2)C1(C)C</smiles>

16<smiles>C=CC(C)=CCC=C(C)C</smiles>
2<smiles>C=C(C)[C@H]1CC=C(C)CC1</smiles><smiles>CC1=CCC(C(C)(C)O)CC1</smiles><smiles>C=C1CCC(C(C)C)C[C@H]1C</smiles>

11<smiles>C=C1C2CC3CC1C3(C)C2</smiles><smiles>Cc1ccccc1C(C)C</smiles>

17
Figure 5. Monoterpenes isolated and/or identified in species of the subtribe Lychnophorinae 
<smiles>C=CC(C)(O)CCC=C(C)CCC=C(C)C</smiles>

18

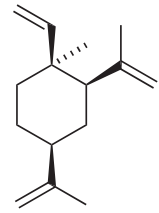

19<smiles>C=C[C@]1(C)CCC(C(C)C)=C[C@H]1C(=C)C</smiles>

20

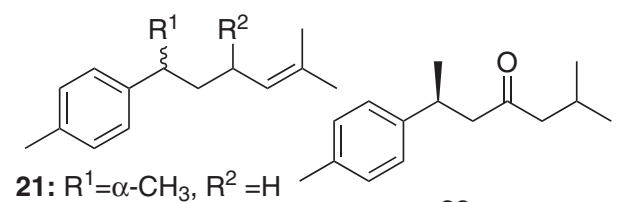

21: $\mathrm{R}^{1}=\alpha-\mathrm{CH}_{3}, \mathrm{R}^{2}=\mathrm{H}$

22: $R^{1}=\beta-\mathrm{CH}_{3}, \mathrm{R}^{2}=\mathrm{OH}$

23<smiles>CC(C)=CC/C=C(/C)[C@H]1CC=C(C)CC1</smiles><smiles>C=C(CCC=C(C)C)C1CC=C(C)CC1</smiles><smiles>CC(C)=CCCC(C)C1=CC=C(C)CC1</smiles><smiles>[R]CC1=CC[C@H]([C@H]([Z4])O)[C@H](C)C1</smiles>

27: $\mathrm{R}=\mathrm{H}$

28: $\mathrm{R}=\mathrm{OH}$

29: $\mathrm{R}=\mathrm{OAC}$<smiles>C=C1CCC([18OH])[C@H](CCC=C(C)C)C1</smiles>

30

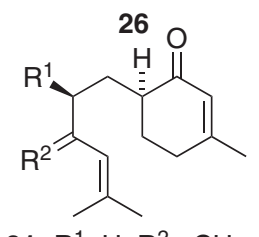

31: $\mathrm{R}^{1}=\mathrm{H}, \mathrm{R}^{2}=\mathrm{CH}_{2}$

32: $R^{1}=H, R^{2}=O$

33: $\mathrm{R}^{1}=\mathrm{OH}, \mathrm{R}^{2}=\mathrm{O}$<smiles>C=C1C=CC(C(C)C)CCC(C)=CC1</smiles>

34<smiles>C=C1CC[C@H](C(C)C)[C@H]2C=C(C)CC[C@H]12</smiles>

35

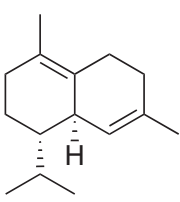

36<smiles>CC1=C[C@@H]2C(C(C)C)CC[C@H](O)[C@H]2CC1</smiles><smiles>CC1=C[C@H]2C(C(C)C)CC[C@H](O)[C@H]2CC1</smiles><smiles>CC1=CC2C(C(C)C)CCC(C)C2(O)CC1</smiles>

37

38<smiles>C=C1C=CC(C(C)C)CCC2=CCCC(C)=C12</smiles>

40<smiles>C=C1CCC[C@]2(C)CCC([C@@H](OC(=O)O)[C@H]3CC=C4CC[C@@H](C(=C)C)C[C@]4(C)[C@H]3C)C[C@H]12</smiles>

42<smiles>C=C1CCC[C@@H](C(=O)O)CC[C@H]2C[C@H](C)[C@H]1C2</smiles>

43: $\mathrm{R}=\mathrm{H}$

44: $\mathrm{R}=\mathrm{CH}_{3}$

55: $\mathrm{R}=\mathrm{CHO}$

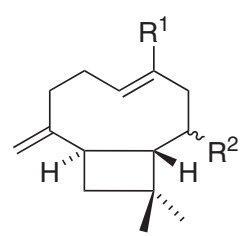

45: $\mathrm{R}^{1}=\mathrm{CH}_{3}, \mathrm{R}^{2}=\mathrm{H}$

46: $\mathrm{R}^{1}=\mathrm{CO}_{2} \mathrm{H}, \mathrm{R}^{2}=\mathrm{H}$

47: $\mathrm{R}^{1}=\mathrm{CO}_{2} \mathrm{H}, \mathrm{R}^{2}=\beta-\mathrm{OH}$

48: $R^{1}=\mathrm{CO}_{2} \mathrm{CH}_{3}, \mathrm{R}^{2}=\mathrm{H}$

49: $\mathrm{R}^{1}=\mathrm{CO}_{2} \mathrm{H}, \mathrm{R}^{2}=\alpha-\mathrm{OH}$

50: $\mathrm{R}^{1}=\mathrm{CO}_{2} \mathrm{CH}_{3}, \mathrm{R}^{2}=\alpha-\mathrm{OH}$

51: $\mathrm{R}^{1}=\mathrm{CO}_{2} \mathrm{H}, \mathrm{R}^{2}=\alpha-\mathrm{OAC}$
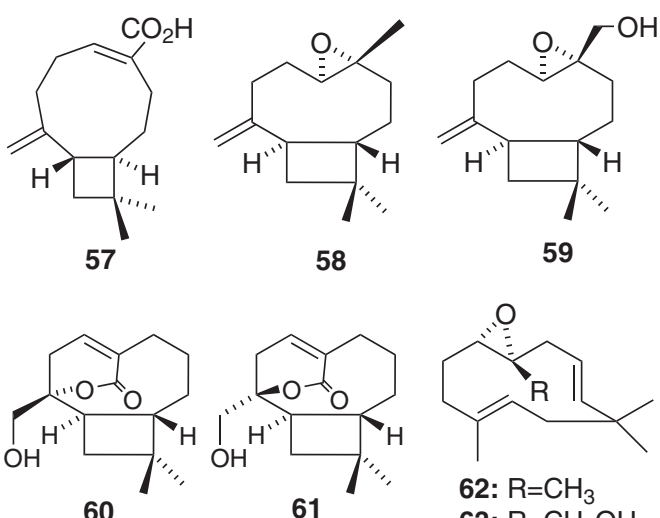

62: $\mathrm{R}=\mathrm{CH}_{3}$

63: $\mathrm{R}=\mathrm{CH}_{2} \mathrm{OH}$

64: $\mathrm{R}=\mathrm{CHO}$

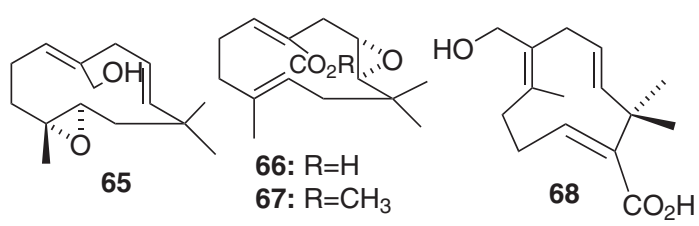<smiles>CC1=CC23CCC(C)=C2CCC3C1(C)C</smiles>

$69^{\star}$

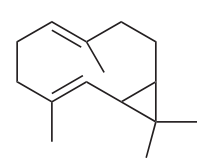

70*<smiles>CC1=CC[C@H]2C(C)CC[C@@H](C(C)C)[C@H]12</smiles>

73<smiles>CC1CCC=C2CCC3C(C3(C)C)C21C</smiles>

$71^{*}$

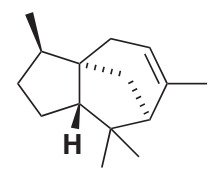

74<smiles>CC1=C2CC[C@@H](C)[C@@H]2CC([13CH3])CC1</smiles><smiles>CC1=CC[C@H]([C@H]2CC[C@@H](O)C(C)(C)O2)CC1</smiles><smiles>[2H][C@@H]1[C@@H]2CC[C@H](C(C)C)[C@H]2[C@@H]1[2H]</smiles>

78

79<smiles></smiles>

80

56: $\mathrm{R}=\mathrm{CO}_{2} \mathrm{H}$

Figure 7. Sesquiterpenes isolated and/or identified in species of the subtribe Lychnophorinae. *Configurations of the stereocenters were not shown in the original papers 
<smiles>[R]CC1=C[C@@H]2OC(=O)C(=C)[C@@H]2[C@H](OC([R])=O)C[C@@]2(C)OC1=CC2=O</smiles>

83-97

$\begin{array}{lcc} & \mathrm{R}^{1} & \mathrm{R}^{2} \\ 83 & \mathrm{H} & \mathrm{A} \\ 84 & \mathrm{OH} & \mathrm{A} \\ 85 & \text { OAC } & \mathrm{A} \\ 86 & \mathrm{H} & \mathrm{B} \\ 87 & \mathrm{H} & \mathrm{C} \\ 88 & \mathrm{H} & \mathrm{D}\end{array}$

$A=\xi \quad B=\xi Y$

$C=\xi K_{0} \quad D=\xi$

$E=\xi \quad G=\xi \xi_{O}$

$\mathrm{Y}=$ 乡 $\mathrm{w}=\mathrm{y}_{\mathrm{J}}$

$\mathrm{Z}=\mathrm{f}_{\mathrm{OH}}^{\mathrm{OH}}$
$89 \mathrm{H}$

$90 \mathrm{OH} \quad \mathrm{D}$

$92 \mathrm{OH} \quad \mathrm{Y}$

93 OAc $Y$

$94 \quad \mathrm{H} \quad \mathrm{W}$

$95 \mathrm{H}$

$97 \mathrm{H} \quad \mathrm{E}$
$91 \mathrm{H} \quad \mathrm{Y}$

$96 \mathrm{H} \quad \mathrm{Z}$<smiles>[R]C1C(=O)O[C@@H]2C([R])C3=CC(=O)[C@@](C)(C[C@H](O[2H])[C@H]12)O3</smiles>

102-115

$\begin{array}{rlccc} & \mathrm{R}^{1} & \mathrm{R}^{2} & \mathrm{R}^{3} & \mathrm{R}^{4} \\ 102 & \alpha-\mathrm{CH}_{3} & \mathrm{H} & \mathrm{A} & =\mathrm{CH}_{2} \\ 103 & \beta-\mathrm{CH}_{3} & \mathrm{H} & \text { A } & =\mathrm{CH}_{2} \\ 104 & \alpha-\mathrm{CH}_{3} & \beta-\mathrm{OH} & \text { A } & =\mathrm{CH}_{2} \\ 105 & \alpha-\mathrm{CH}_{3} & \beta-\mathrm{OH} & \mathrm{B} & =\mathrm{CH}_{2} \\ 106 & \alpha-\mathrm{CH}_{3} & \mathrm{H} & \mathrm{C} & =\mathrm{CH}_{2} \\ 107 & \alpha-\mathrm{CH}_{3} & \mathrm{H} & \mathrm{Z} & =\mathrm{CH}_{2} \\ 108 & \alpha-\mathrm{CH}_{3} & \mathrm{H} & \mathrm{D} & =\mathrm{CH}_{2} \\ 109 & \alpha-\mathrm{CH}_{3} & \mathrm{H} & \text { D } & \alpha-\mathrm{CH}_{3} \\ 110 & \alpha-\mathrm{CH}_{3} & \mathrm{H} & \mathrm{Y} & =\mathrm{CH}_{2} \\ 111 & \alpha-\mathrm{CH}_{3} & \beta-\mathrm{OH} & W & =\mathrm{CH}_{2} \\ 112 & =\mathrm{CH}_{2} & \alpha-\mathrm{OH} & \text { A } & =\mathrm{CH}_{2} \\ 113 & =\mathrm{CH}_{2} & \beta-\mathrm{OH} & \text { A } & =\mathrm{CH}_{2} \\ 114 & =\mathrm{CH}_{2} & \alpha-\mathrm{OH} & \mathrm{Y} & =\mathrm{CH}_{2} \\ 115 & =\mathrm{CH}_{2} & \beta-\mathrm{OH} & \mathrm{Y} & =\mathrm{CH}_{2}\end{array}$

$102 \alpha-\mathrm{CH}_{3} \quad \mathrm{H} \quad \mathrm{A}=\mathrm{CH}_{2}$

$103 \mathrm{~B}^{-\mathrm{CH}_{3}} \quad \mathrm{H} \quad \mathrm{A}=\mathrm{CH}_{2}$

$104 \alpha-\mathrm{CH}_{3} \quad \beta-\mathrm{OH} \quad \mathrm{A}=\mathrm{CH}_{2}$

$106 \alpha-\mathrm{CH}_{3} \quad \mathrm{H} \quad \mathrm{C} \quad=\mathrm{CH}_{2}$

$109 \alpha-\mathrm{CH}_{3} \quad \mathrm{H} \quad$ D $\alpha-\mathrm{CH}_{3}$

$=\mathrm{CH}_{2}$

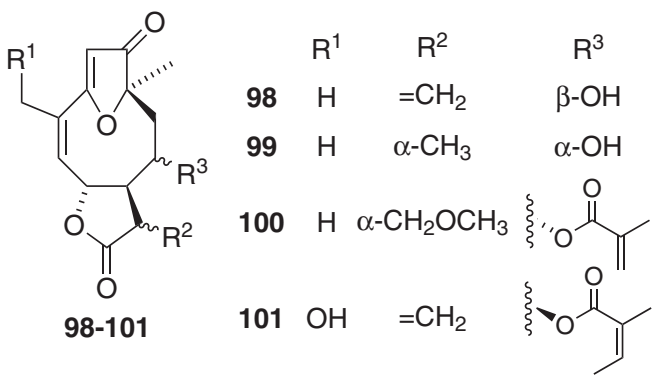

Figure 8. Furanoeliangolides of the goyazensolide type isolated and/or identified from species of the subtribe Lychnophorinae

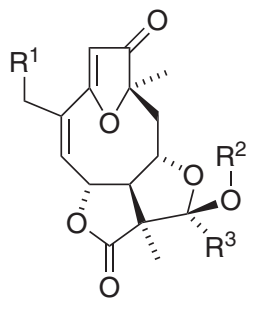

116-136

$$
\begin{aligned}
& A=\xi \quad B=\xi Y \quad C=\xi E_{0} \\
& D=\xi \quad E=\xi Y \quad G=\xi K_{O} \\
& \mathrm{Y}=\xi_{\mathrm{I}} \mathrm{w}=\mathrm{fo}_{\mathrm{O}} \mathrm{z}=\mathrm{f}_{\mathrm{OH}}^{\mathrm{OH}}
\end{aligned}
$$$$
R^{1} \quad R^{2} \quad R^{3}
$$$$
116 \quad \mathrm{H} \quad \mathrm{H} \quad \mathrm{A}
$$$$
117 \mathrm{OH} \quad \mathrm{H} \quad \mathrm{A}
$$$$
127 \text { OAC H E }
$$$$
118 \text { OAC } \mathrm{H} \quad \mathrm{A}
$$$$
128
$$$$
129
$$$$
119 \mathrm{H} \quad \mathrm{H} \quad \mathrm{B}
$$$$
130 \quad \mathrm{H} \quad \mathrm{C}_{2} \mathrm{H}_{5} \quad \mathrm{Y}
$$$$
120 \mathrm{H} \quad \mathrm{H} \quad \mathrm{C}
$$$$
131 \mathrm{OH} \quad \mathrm{H} \quad \mathrm{Y}
$$$$
121 \mathrm{H} \quad \mathrm{H} \quad \mathrm{D}
$$$$
132 \mathrm{OH} \quad \mathrm{CH}_{3} \quad \mathrm{Y}
$$$$
122 \quad \mathrm{H} \quad \mathrm{H} \quad \mathrm{D}
$$$$
133 \mathrm{OH} \quad \mathrm{C}_{2} \mathrm{H}_{5} \quad \mathrm{Y}
$$$$
123 \text { OAC H D }
$$$$
124 \quad \mathrm{H} \quad \mathrm{H} \quad \mathrm{G}
$$$$
134 \text { OAC } \mathrm{H} \quad \mathrm{Y}
$$$$
125 \mathrm{H} \quad \mathrm{H} \quad \mathrm{E}
$$$$
135 \mathrm{H} \quad \mathrm{H} \quad \mathrm{W}
$$$$
136 \quad \mathrm{H} \quad \mathrm{H} \quad \mathrm{Z}
$$

$126 \mathrm{OH} \quad \mathrm{H} \quad \mathrm{E}$

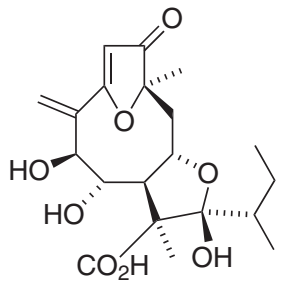

137<smiles>[R16][R15]([H])([H])[H]</smiles>

138-146

$\begin{array}{llllllll}R^{1} & R^{2} & R^{3} & R^{4} & R^{1} & R^{2} & R^{3} & R^{4}\end{array}$ $138 \beta-\mathrm{CH}_{3} \quad \mathrm{H} \quad \mathrm{H} \quad \mathrm{A} \quad 143 \quad \beta-\mathrm{CH}_{3} \quad \mathrm{H} \quad \mathrm{H} \quad \mathrm{Y}$ $139 \alpha-\mathrm{CH}_{3} \quad \mathrm{H} \quad \mathrm{H} \quad \mathrm{A} \quad 144 \alpha-\mathrm{CH}_{3} \quad \mathrm{H} \quad \mathrm{OCH}_{3} \mathrm{Y}$ $140 \beta-\mathrm{CH}_{3} \beta-\mathrm{OH} \quad \mathrm{H} \quad$ В $145 \alpha-\mathrm{CH}_{3} \quad \mathrm{H} \quad \mathrm{H} \quad$ Y

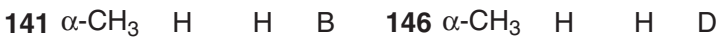
$142 \alpha-\mathrm{CH}_{3} \quad \mathrm{H} \quad \mathrm{H} \quad \mathrm{C}$ 
<smiles></smiles>

147

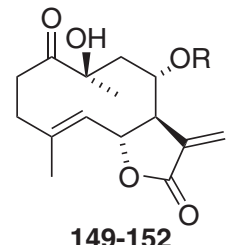

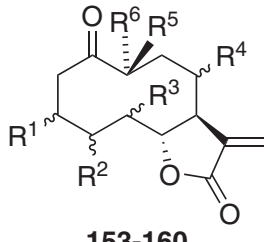

$153-160$<smiles>C=C1C(=O)O[C@@H]2O[C@H]3C(=CCC[C@]3(C)O)CCC12</smiles>

148<smiles>CC(C)CCCCC(=O)C(C)C</smiles><smiles>O=C(C#P)C(O)(CO)CO</smiles>

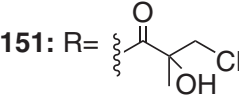

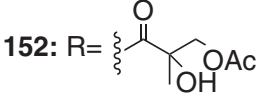

$153 \quad \mathrm{H} \quad \beta-\mathrm{CH}_{3} \mathrm{OH} \alpha$-OMeAcr $\mathrm{OAc} \mathrm{CH}_{3}$

$154 \quad \mathrm{H} \quad \beta-\mathrm{CH}_{3} \quad \mathrm{H} \quad \alpha$-OMeAcr $\mathrm{OAc} \mathrm{CH}_{3}$

$155 \beta-\mathrm{OH} \quad \beta-\mathrm{CH}_{3} \quad \mathrm{H} \quad \beta$-OAng $\quad \mathrm{CH}_{3} \quad \mathrm{OAc}$

$156 \alpha-\mathrm{OH} \quad \alpha-\mathrm{CH}_{3} \quad \mathrm{H} \quad \alpha$-OAng $\quad \mathrm{OAc} \quad \mathrm{CH}_{3}$

$157 \quad \beta-\mathrm{OH} \quad \alpha-\mathrm{CH}_{3} \quad \mathrm{H} \quad \alpha$-OAng $\quad \mathrm{OAc}^{\mathrm{CH}_{3}}$

$158 \beta-\mathrm{OCH}_{3} \alpha-\mathrm{CH}_{3} \quad \mathrm{H} \quad \alpha-\mathrm{OMeAcr} \mathrm{OAc} \mathrm{CH}_{3}$

$159 \quad \mathrm{H} \quad \alpha-\mathrm{CH}_{3} \quad \mathrm{H} \quad \alpha$-OAng $\mathrm{OAc} \mathrm{CH}_{3}$

$160 \quad \mathrm{H} \quad \alpha-\mathrm{CH}_{3} \quad \mathrm{H} \quad \alpha$-OAng $\mathrm{OAc} \mathrm{CH}_{3}$

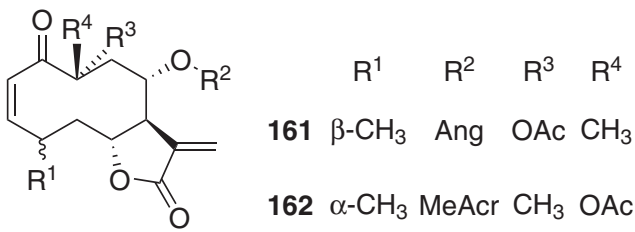

161-162

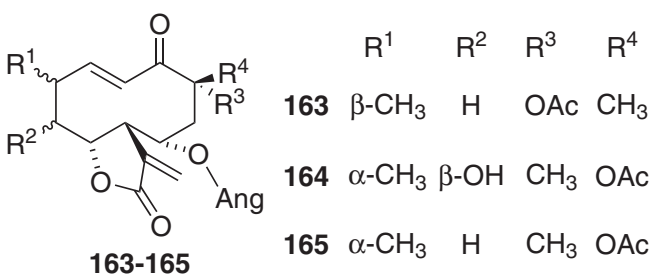

Figure 10. Germacranolides isolated and/or identified from species of subtribe Lychnophorinae

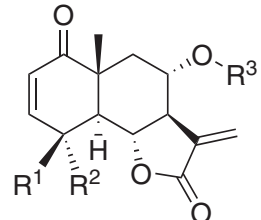

166-172<smiles>[R]C1CC=C(C)C2[C@@H]3OC(=O)C(=C)[C@H]3CC[C@]12C</smiles>

173: $\mathrm{R}=\mathrm{H}$

174: $\mathrm{R}=\beta-\mathrm{OH}$<smiles>C=C1C(=O)O[C@H]2C1CC[C@H]1[C@@H]2OC(=O)CC[C@@H]1C(F)(F)F</smiles>

175<smiles>C=C1C(=O)O[C@H]2C1=CCC[C@H](O)[C@@H]2C</smiles><smiles>[R7]C1CCC[C@]2(C)CC[C@H]3C(=C)C(=O)O[C@@H]3[C@H]12</smiles>

177: $\mathrm{R}^{1}=\mathrm{CH}_{3}, \mathrm{R}^{2}=\mathrm{OH}$ 178: $\mathrm{R}^{1}=\mathrm{OH}, \mathrm{R}^{2}=\mathrm{CH}_{3}$

Figure 11. Eudesmanolides isolated and/or identified from species of subtribe Lychnophorinae
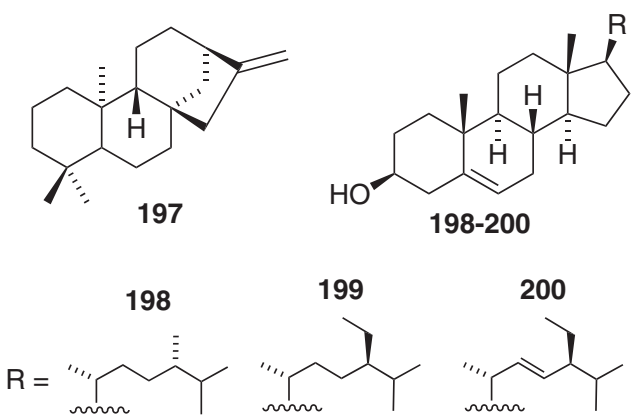

Figure 13. Steroids isolated and/or identified in species of the subtribe Lychnophorinae 


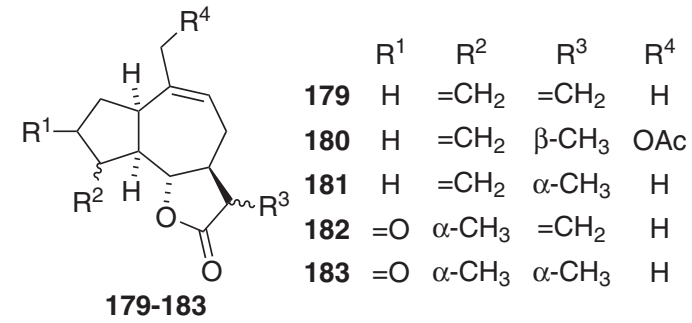

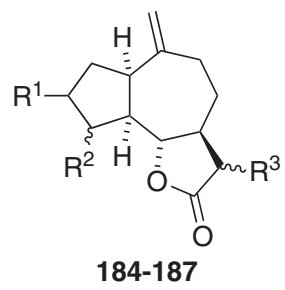

$\begin{array}{rccc} & \mathrm{R}^{1} & \mathrm{R}^{2} & \mathrm{R}^{3} \\ 184 & \mathrm{H} & =\mathrm{CH}_{2} & =\mathrm{CH}_{2} \\ 185 & =\mathrm{O} & =\mathrm{CH}_{2} & =\mathrm{CH}_{2} \\ 186 & =\mathrm{O} & \alpha-\mathrm{CH}_{3} & =\mathrm{CH}_{2} \\ 187 & =\mathrm{O} & \alpha-\mathrm{CH}_{3} & \alpha-\mathrm{CH}_{3}\end{array}$
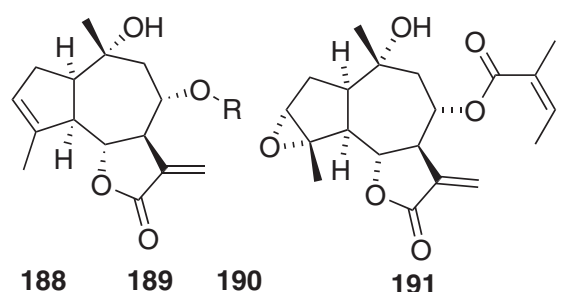

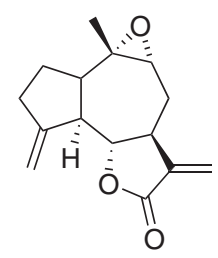

192

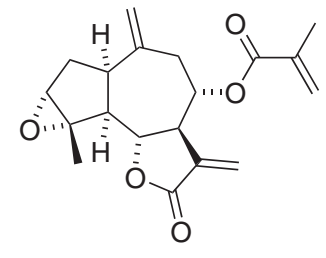

193

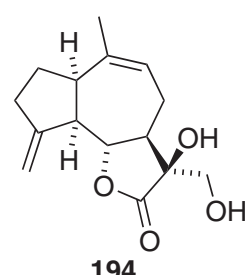

194

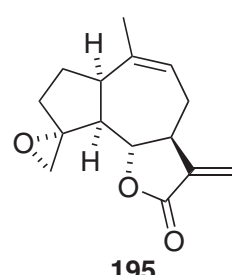

195

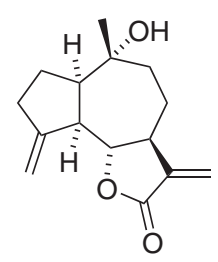

196

Figure 12. Guaianolides isolated and/or identified in species of the subtribe Lychnophorinae<smiles>CC(C)=CCCC(C)=CCCC1=C(C)CCC=C1C</smiles>

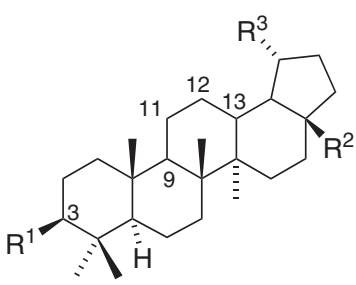

202-214

\begin{tabular}{|c|c|c|c|c|}
\hline & $\mathrm{R}^{1}$ & $\mathrm{R}^{2}$ & $\Delta$ & $\mathrm{R}^{3}$ \\
\hline 202 & $\mathrm{OH}$ & $\mathrm{CH}_{3}$ & ---- & \\
\hline 203 & OAc & $\mathrm{CH}_{3}$ & --- & \\
\hline 204 & $=0$ & $\mathrm{CH}_{3}$ & ---- & \\
\hline 205 & $\mathrm{OH}$ & $\mathrm{CO}_{2} \mathrm{H}$ & --- & \\
\hline 206 & OAc & $\mathrm{CO}_{2} \mathrm{H}$ & ---- & \\
\hline 207 & $\mathrm{OH}$ & $\mathrm{CH}_{3}$ & ---- & \\
\hline 208 & $\mathrm{OH}$ & $\mathrm{CH}_{3}$ & ---- & \\
\hline
\end{tabular}

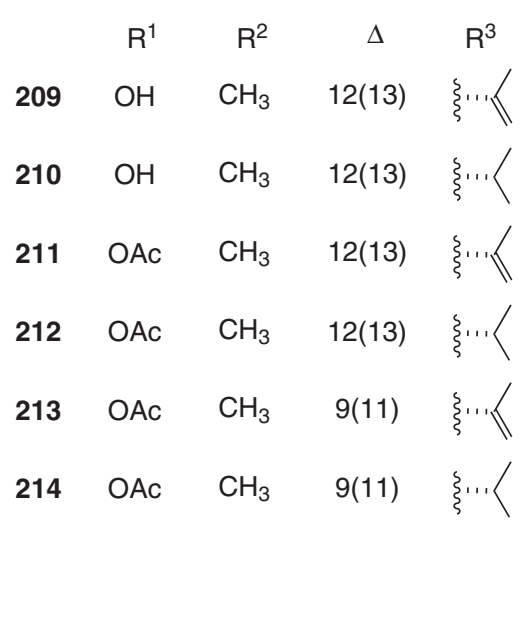

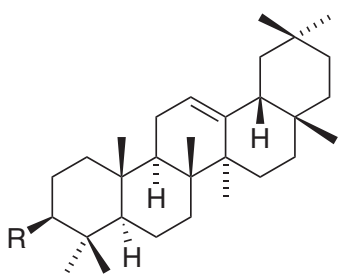

223: $\mathrm{R}=\mathrm{OH}$

224: $\mathrm{R}=\mathrm{OAc}$

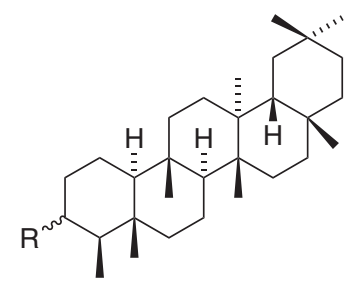

225: $\mathrm{R}=\alpha-\mathrm{OH}$

226: $\mathrm{R}=\beta-\mathrm{OH}$

227: $\mathrm{R}=\mathrm{=O}$

216: $\mathrm{R}=\mathrm{OAc}, \Delta^{20,30}$

217: $\mathrm{R}==\mathrm{O}, \Delta^{20,30}$

221: $R^{1}=\mathrm{OAc}, \mathrm{R}^{2}=\mathrm{CH}_{3}$

222: $R^{1}=\mathrm{OH}, \mathrm{R}^{2}=\mathrm{CO}_{2} \mathrm{H}$

218: $\mathrm{R}=\mathrm{OH}, \Delta^{20,21}$
219: $\mathrm{R}=\mathrm{OAc}, \Delta^{20,21}$

Figure 14. Triterpenes isolated and/or identified in species of the subtribe Lychnophorinae 


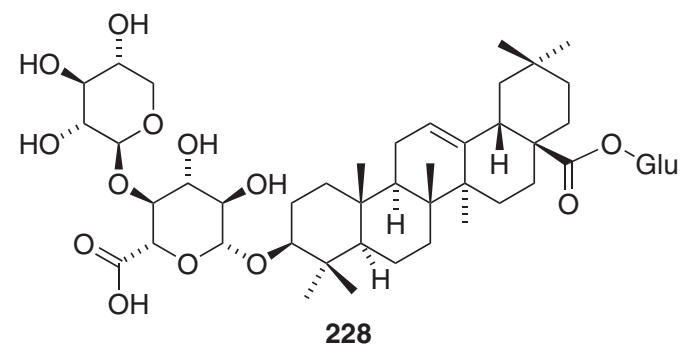

Figure 15. Triterpene saponin isolated and/or identified in species of the subtribe Lychnophorinae<smiles>COc1ccc(C=O)cc1O</smiles><smiles>COc1cc(C(=O)O)ccc1O</smiles>

233<smiles>[R]c1cc(CC=C)cc([R])c1OC</smiles>

235-237<smiles>[R7]C(=Cc1ccc([R])c([R])c1)[R16]([R])([R])[H]</smiles>

$\begin{array}{ccccc} & \mathrm{R}^{1} & \mathrm{R}^{2} & \mathrm{R}^{3} & \mathrm{R}^{4} \\ \mathbf{2 3 8} & \mathrm{H} & \mathrm{H} & \mathrm{CO}_{2} \mathrm{H} & \mathrm{H} \\ \mathbf{2 3 9} & \mathrm{H} & \mathrm{OCH}_{3} & \mathrm{CO}_{2} \mathrm{H} & \mathrm{H} \\ \mathbf{2 4 0} & \mathrm{OCH}_{3} & \mathrm{OH} & \mathrm{CHO} & \mathrm{H} \\ \mathbf{2 4 1} & \mathrm{OH} & \mathrm{OH} & \mathrm{CO}_{2} \mathrm{H} & \mathrm{H} \\ \mathbf{2 4 2} & \mathrm{OCH}_{3} & \mathrm{OH} & \mathrm{CH}_{2} \mathrm{O}-\mathrm{Val} & \mathrm{H} \\ \mathbf{2 4 3} & \mathrm{H} & \mathrm{OH} & \mathrm{HEDP} & \mathrm{H} \\ \mathbf{2 4 4} & \mathrm{H} & \mathrm{OH} & \mathrm{H} & \mathrm{HEDP}\end{array}$

Figure 17. Benzoic acid derivatives (233 and 234) and Phenylpropanoids (235 to 244) isolated and/or identified in species of the subtribe Lychnophorinae<smiles>[R]C/C=C(/C)CC(C)/C=C(\C)CC(C)C/C=C(/C)C[R]</smiles>
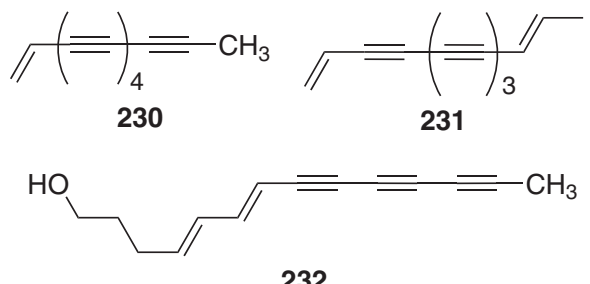

Figure 16. Poliisoprene and acetylene derivatives isolated and/or identified in species of the subtribe Lychnophorinae<smiles>[R]C[C@H]1OC[C@H]([R])[C@H]1C[R]</smiles>

245-253<smiles>CC(C)(C)c1ccc2c(c1)OCO2</smiles>

$\mathrm{R}^{1} \quad \mathrm{R}^{2} \quad \mathrm{R}^{3}$

$245 \alpha-\mathrm{OH} \quad \mathrm{Pi} \quad \mathrm{Pi}$

$246 \quad \beta-O H \quad P i \quad P i$

$247 \alpha-\mathrm{OCH}_{3}$ Tf $\mathrm{Pi}$

$248 \mathrm{~B}^{-\mathrm{OCH}_{3}}$ Tf $\mathrm{Pi}$

$249 \alpha-\mathrm{OCH}_{3} \quad \mathrm{Pi} \quad \mathrm{Pi}$

$250 \quad \mathrm{BCCH}_{3} \quad \mathrm{Pi} \quad \mathrm{Pi}$

$251=\mathrm{P} \quad \mathrm{Pi} \quad \mathrm{Pi}$

$252=\mathrm{O}$ Tf $\mathrm{Pi}$

$253=0 \quad$ Tf $\quad$ Tf

Figure 18. Lignans isolated and/or identified in species of the subtribe Lychnophorinae 
<smiles></smiles>

\begin{tabular}{|c|c|c|c|c|c|c|c|c|}
\hline & $\mathrm{R}^{1}$ & $\mathrm{R}^{2}$ & $\mathrm{R}^{3}$ & $\mathrm{R}^{4}$ & $\mathrm{R}^{5}$ & $\mathrm{R}^{6}$ & $\mathrm{R}^{7}$ & $\mathrm{R}^{8}$ \\
\hline 255 & $\mathrm{H}$ & $\mathrm{OH}$ & $\mathrm{OH}$ & $\mathrm{H}$ & $\mathrm{H}$ & $\mathrm{H}$ & $\mathrm{H}$ & $\mathrm{H}$ \\
\hline 256 & $\mathrm{H}$ & $\mathrm{OH}$ & $\mathrm{OH}$ & $\mathrm{H}$ & $\mathrm{H}$ & $\mathrm{H}$ & Glu & Glu \\
\hline 257 & $\mathrm{H}$ & $\mathrm{OH}$ & $\mathrm{OH}$ & $\mathrm{OH}$ & $\mathrm{H}$ & $\mathrm{H}$ & $\mathrm{H}$ & $\mathrm{H}$ \\
\hline 258 & $\mathrm{H}$ & $\mathrm{OH}$ & $\mathrm{OH}$ & $\mathrm{OH}$ & $\mathrm{H}$ & $\mathrm{H}$ & Glu & Glu \\
\hline 259 & $\mathrm{H}$ & $\mathrm{OH}$ & $\mathrm{OH}$ & $\mathrm{OH}$ & $\mathrm{H}$ & $\mathrm{OH}$ & Glu & Glu \\
\hline 260 & $\mathrm{H}$ & $\mathrm{OH}$ & $\mathrm{OH}$ & $\mathrm{OH}$ & $\mathrm{H}$ & $\mathrm{H}$ & Glu & $\mathrm{H}$ \\
\hline 261 & $\mathrm{H}$ & $\mathrm{OH}$ & $\mathrm{OH}$ & $\mathrm{OH}$ & $\mathrm{H}$ & $\mathrm{H}$ & $\mathrm{H}$ & Glu \\
\hline 262 & $\mathrm{H}$ & $\mathrm{OH}$ & $\mathrm{OH}$ & $\mathrm{OH}$ & $\mathrm{OH}$ & $\mathrm{H}$ & $\mathrm{H}$ & $\mathrm{H}$ \\
\hline 263 & $\mathrm{H}$ & $\mathrm{OH}$ & $\mathrm{OH}$ & $\mathrm{OH}$ & $\mathrm{OH}$ & $\mathrm{H}$ & Glu & Glu \\
\hline 264 & $\mathrm{H}$ & $\mathrm{OH}$ & $\mathrm{OH}$ & $\mathrm{OH}$ & $\mathrm{OCH}_{3}$ & $\mathrm{H}$ & $\mathrm{H}$ & $\mathrm{H}$ \\
\hline 265 & $\mathrm{H}$ & $\mathrm{OH}$ & $\mathrm{OH}$ & $\mathrm{OCH}_{3}$ & $\mathrm{H}$ & $\mathrm{H}$ & $\mathrm{H}$ & $\mathrm{H}$ \\
\hline 266 & $\mathrm{H}$ & $\mathrm{OH}$ & $\mathrm{OH}$ & $\mathrm{OCH}_{3}$ & $\mathrm{OCH}_{3}$ & $\mathrm{H}$ & $\mathrm{H}$ & $\mathrm{H}$ \\
\hline 267 & $\mathrm{H}$ & $\mathrm{OH}$ & $\mathrm{OCH}_{3}$ & $\mathrm{H}$ & $\mathrm{H}$ & $\mathrm{H}$ & $\mathrm{H}$ & $\mathrm{H}$ \\
\hline 268 & $\mathrm{H}$ & $\mathrm{OH}$ & $\mathrm{OCH}_{3}$ & $\mathrm{OH}$ & $\mathrm{H}$ & $\mathrm{H}$ & $\mathrm{H}$ & $\mathrm{H}$ \\
\hline 269 & $\mathrm{H}$ & $\mathrm{OH}$ & $\mathrm{OCH}_{3}$ & $\mathrm{OH}$ & $\mathrm{OH}$ & $\mathrm{H}$ & $\mathrm{H}$ & $\mathrm{H}$ \\
\hline 270 & $\mathrm{H}$ & $\mathrm{OH}$ & $\mathrm{OCH}_{3}$ & $\mathrm{OH}$ & $\mathrm{OCH}_{3}$ & $\mathrm{H}$ & $\mathrm{H}$ & $\mathrm{H}$ \\
\hline 271 & $\mathrm{H}$ & $\mathrm{OH}$ & $\mathrm{OCH}_{3}$ & $\mathrm{OH}$ & $\mathrm{OCH}_{3}$ & $\mathrm{H}$ & $\mathrm{H}$ & $\mathrm{OCH}_{3}$ \\
\hline 272 & $\mathrm{H}$ & $\mathrm{OH}$ & $\mathrm{OCH}_{3}$ & $\mathrm{OCH}_{3}$ & $\mathrm{H}$ & $\mathrm{H}$ & $\mathrm{H}$ & $\mathrm{H}$ \\
\hline 273 & $\mathrm{H}$ & $\mathrm{OH}$ & $\mathrm{OCH}_{3}$ & $\mathrm{OCH}_{3}$ & $\mathrm{H}$ & $\mathrm{OCH}_{3}$ & $\mathrm{H}$ & $\mathrm{OCH}_{3}$ \\
\hline 274 & $\mathrm{H}$ & $\mathrm{OH}$ & $\mathrm{OCH}_{3}$ & $\mathrm{OCH}_{3}$ & $\mathrm{OH}$ & $\mathrm{H}$ & $\mathrm{H}$ & $\mathrm{H}$ \\
\hline 275 & $\mathrm{H}$ & $\mathrm{OH}$ & $\mathrm{OCH}_{3}$ & $\mathrm{OCH}_{3}$ & $\mathrm{OH}$ & $\mathrm{H}$ & $\mathrm{H}$ & $\mathrm{H}$ \\
\hline 276 & $\mathrm{H}$ & $\mathrm{OH}$ & $\mathrm{OCH}_{3}$ & $\mathrm{OCH}_{3}$ & $\mathrm{OCH}_{3}$ & $\mathrm{H}$ & $\mathrm{H}$ & $\mathrm{H}$ \\
\hline 277 & $\mathrm{H}$ & $\mathrm{OH}$ & $\mathrm{OCH}_{3}$ & $\mathrm{OCH}_{3}$ & $\mathrm{OCH}_{3}$ & $\mathrm{H}$ & $\mathrm{H}$ & $\mathrm{OCH}_{3}$ \\
\hline 278 & $\mathrm{OH}$ & $\mathrm{H}$ & $\mathrm{OH}$ & $\mathrm{OH}$ & $\mathrm{H}$ & $\mathrm{H}$ & $\mathrm{H}$ & $\mathrm{H}$ \\
\hline 279 & $\mathrm{OH}$ & $\mathrm{OH}$ & $\mathrm{OH}$ & $\mathrm{H}$ & $\mathrm{H}$ & $\mathrm{H}$ & $\mathrm{H}$ & $\mathrm{H}$ \\
\hline 280 & $\mathrm{OH}$ & $\mathrm{OH}$ & $\mathrm{OH}$ & $\mathrm{OH}$ & $\mathrm{H}$ & $\mathrm{H}$ & $\mathrm{H}$ & $\mathrm{H}$ \\
\hline 281 & $\mathrm{OH}$ & $\mathrm{OH}$ & $\mathrm{OH}$ & $\mathrm{OH}$ & $\mathrm{OH}$ & $\mathrm{H}$ & $\mathrm{H}$ & $\mathrm{H}$ \\
\hline 282 & $\mathrm{OH}$ & $\mathrm{OH}$ & $\mathrm{OH}$ & $\mathrm{OH}$ & $\mathrm{OCH}_{3}$ & $\mathrm{H}$ & $\mathrm{H}$ & $\mathrm{H}$ \\
\hline 283 & $\mathrm{OH}$ & $\mathrm{OH}$ & $\mathrm{OH}$ & $\mathrm{OCH}_{3}$ & $\mathrm{OH}$ & $\mathrm{H}$ & $\mathrm{H}$ & $\mathrm{H}$ \\
\hline 284 & $\mathrm{OH}$ & $\mathrm{OH}$ & $\mathrm{OCH}_{3}$ & $\mathrm{H}$ & $\mathrm{H}$ & $\mathrm{H}$ & $\mathrm{H}$ & $\mathrm{H}$ \\
\hline 285 & $\mathrm{OH}$ & $\mathrm{OH}$ & $\mathrm{OCH}_{3}$ & $\mathrm{OH}$ & $\mathrm{H}$ & $\mathrm{H}$ & $\mathrm{H}$ & $\mathrm{H}$ \\
\hline 286 & $\mathrm{OH}$ & $\mathrm{OH}$ & $\mathrm{OCH}_{3}$ & $\mathrm{OH}$ & $\mathrm{OCH}_{3}$ & $\mathrm{H}$ & $\mathrm{H}$ & $\mathrm{H}$ \\
\hline 287 & $\mathrm{OH}$ & $\mathrm{OH}$ & $\mathrm{OCH}_{3}$ & $\mathrm{OCH}_{3}$ & $\mathrm{OCH}_{3}$ & $\mathrm{H}$ & $\mathrm{H}$ & $\mathrm{H}$ \\
\hline 288 & $\mathrm{OCH}_{3}$ & $\mathrm{OH}$ & $\mathrm{OH}$ & $\mathrm{H}$ & $\mathrm{H}$ & $\mathrm{H}$ & $\mathrm{H}$ & $\mathrm{H}$ \\
\hline 289 & $\mathrm{OCH}_{3}$ & $\mathrm{OH}$ & $\mathrm{OH}$ & $\mathrm{OH}$ & $\mathrm{H}$ & $\mathrm{H}$ & $\mathrm{H}$ & $\mathrm{H}$ \\
\hline 290 & $\mathrm{OCH}_{3}$ & $\mathrm{OH}$ & $\mathrm{OH}$ & $\mathrm{OH}$ & $\mathrm{H}$ & $\mathrm{OH}$ & $\mathrm{H}$ & $\mathrm{OH}$ \\
\hline 291 & $\mathrm{OCH}_{3}$ & $\mathrm{OH}$ & $\mathrm{OH}$ & $\mathrm{OH}$ & $\mathrm{OH}$ & $\mathrm{H}$ & $\mathrm{H}$ & $\mathrm{H}$ \\
\hline 292 & $\mathrm{OCH}_{3}$ & $\mathrm{OH}$ & $\mathrm{OH}$ & $\mathrm{OCH}_{3}$ & $\mathrm{H}$ & $\mathrm{H}$ & $\mathrm{H}$ & $\mathrm{H}$ \\
\hline 293 & $\mathrm{OCH}_{3}$ & $\mathrm{OH}$ & $\mathrm{OCH}_{3}$ & $\mathrm{OH}$ & $\mathrm{H}$ & $\mathrm{H}$ & $\mathrm{H}$ & $\mathrm{H}$ \\
\hline 294 & $\mathrm{OCH}_{3}$ & $\mathrm{OH}$ & $\mathrm{OCH}_{3}$ & $\mathrm{OH}$ & $\mathrm{OCH}_{3}$ & $\mathrm{H}$ & $\mathrm{H}$ & $\mathrm{H}$ \\
\hline 295 & $\mathrm{OCH}_{3}$ & $\mathrm{OH}$ & $\mathrm{OCH}_{3}$ & $\mathrm{OCH}_{3}$ & $\mathrm{H}$ & $\mathrm{H}$ & $\mathrm{H}$ & $\mathrm{H}$ \\
\hline 296 & $\mathrm{OCH}_{3}$ & $\mathrm{OH}$ & $\mathrm{OCH}_{3}$ & $\mathrm{OCH}_{3}$ & $\mathrm{OH}$ & $\mathrm{H}$ & $\mathrm{H}$ & $\mathrm{H}$ \\
\hline 297 & $\mathrm{OCH}_{3}$ & $\mathrm{OH}$ & $\mathrm{OCH}_{3}$ & $\mathrm{OCH}_{3}$ & $\mathrm{OCH}_{3}$ & $\mathrm{H}$ & $\mathrm{H}$ & $\mathrm{H}$ \\
\hline 298 & $\mathrm{OCH}_{3}$ & $\mathrm{OH}$ & $\mathrm{OCH}_{3}$ & $\mathrm{OCH}_{3}$ & $\mathrm{OH}$ & $\mathrm{OCH}_{3}$ & $\mathrm{H}$ & $\mathrm{H}$ \\
\hline 299 & OGlu & $\mathrm{OH}$ & $\mathrm{OH}$ & $\mathrm{OH}$ & $\mathrm{OH}$ & $\mathrm{H}$ & $\mathrm{H}$ & $\mathrm{H}$ \\
\hline 300 & OGlu & $\mathrm{OH}$ & $\mathrm{OH}$ & $\mathrm{OH}$ & $\mathrm{OCH}_{3}$ & $\mathrm{H}$ & $\mathrm{H}$ & $\mathrm{H}$ \\
\hline
\end{tabular}

Figure 19. Flavones (254 to 276) and flavonols (277 to 300) identified in species of the subtribe Lychnophorinae<smiles>[R]c1cc([12H])cc2c1C(=O)C([R3])[C@H](c1ccc(P)c(P)c1)O2</smiles>

\begin{tabular}{|c|c|c|c|c|c|}
\hline & $\mathrm{R}^{1}$ & $\mathrm{R}^{2}$ & $\mathrm{R}^{3}$ & $\mathrm{R}^{4}$ & $\mathrm{R}^{5}$ \\
\hline 301 & $\mathrm{H}$ & $\mathrm{OH}$ & $\mathrm{OH}$ & $\mathrm{H}$ & $\mathrm{H}$ \\
\hline 302 & $\mathrm{H}$ & $\mathrm{OH}$ & $\mathrm{OH}$ & $\mathrm{OH}$ & $\mathrm{H}$ \\
\hline 303 & $\mathrm{H}$ & $\mathrm{OH}$ & $\mathrm{OH}$ & $\mathrm{OH}$ & $\mathrm{OH}$ \\
\hline 304 & $\mathrm{H}$ & $\mathrm{OH}$ & $\mathrm{OH}$ & $\mathrm{OH}$ & $\mathrm{OCH}_{3}$ \\
\hline 305 & $\mathrm{H}$ & $\mathrm{OH}$ & $\mathrm{OCH}_{3}$ & $\mathrm{H}$ & $\mathrm{H}$ \\
\hline 306 & $\mathrm{H}$ & $\mathrm{OH}$ & $\mathrm{OCH}_{3}$ & $\mathrm{OH}$ & $\mathrm{H}$ \\
\hline 307 & $\mathrm{H}$ & $\mathrm{OH}$ & $\mathrm{OCH}_{3}$ & $\mathrm{OH}$ & $\mathrm{OCH}_{3}$ \\
\hline 308 & $\mathrm{H}$ & $\mathrm{OH}$ & $\mathrm{OCH}_{3}$ & $\mathrm{OCH}_{3}$ & $\mathrm{OH}$ \\
\hline 309 & $\mathrm{H}$ & $\mathrm{H}$ & $\mathrm{OH}$ & $\mathrm{OCH}_{3}$ & $\mathrm{H}$ \\
\hline 310 & $\mathrm{OH}$ & $\mathrm{H}$ & $\mathrm{OH}$ & $\mathrm{OH}$ & $\mathrm{H}$ \\
\hline 311 & $\mathrm{OH}$ & $\mathrm{OH}$ & $\mathrm{OH}$ & $\mathrm{H}$ & $\mathrm{H}$ \\
\hline 312 & $\mathrm{OH}$ & $\mathrm{OH}$ & $\mathrm{OCH}_{3}$ & $\mathrm{H}$ & $\mathrm{H}$ \\
\hline 313 & $\mathrm{OH}$ & $\mathrm{OH}$ & $\mathrm{OH}$ & $\mathrm{OH}$ & $\mathrm{OCH}_{3}$ \\
\hline 314 & $O A C$ & $\mathrm{OH}$ & $\mathrm{OH}$ & $\mathrm{H}$ & $\mathrm{H}$ \\
\hline 315 & OAc & $\mathrm{OH}$ & $\mathrm{OCH}_{3}$ & $\mathrm{H}$ & $\mathrm{H}$ \\
\hline 316 & $\mathrm{OCOC}_{2} \mathrm{H}_{5}$ & $\mathrm{OH}$ & $\mathrm{OCH}_{3}$ & $\mathrm{H}$ & $\mathrm{H}$ \\
\hline
\end{tabular}<smiles>[R]Oc1cc(O)c(C(=O)/C=C/c2ccccc2)c(O)c1</smiles>

317: $\mathrm{R}=\mathrm{H}$ 318: $\mathrm{R}=\mathrm{CH}_{3}$<smiles>O=C(/C=C/c1ccc(O)cc1)OCCC(O)C(O)COc1c(-c2ccc(O)c(P)c2)oc2cc(O)cc(O)c2c1=O</smiles>

319: $\mathrm{R}=\mathrm{H}$

320: $\mathrm{R}=\mathrm{OCH}_{3}$<smiles>O=C(/C=C/c1ccc(OC(O)C(O)CO)cc1)Oc1c(-c2ccc(O)cc2)oc2cc(O)cc(O)c2c1=O</smiles>

321

Figure 20. Diidroflavones (301 to 309), diidroflavonols (310 to 316), chalcones (317 and 318) and heteroside flavonoids (319 to 321) identified in species of the subtribe Lychnophorinae 
<smiles>[R7]O[C@H]1C[C@@](O)(C(=O)O)C[C@H](O[B])[C@@H]1O[R]</smiles>

322-334<smiles>O=C(C=[GeH2])C(=O)C=Cc1ccc(O)c(O)c1</smiles><smiles>COc1cc(/C=C/C(=O)CC(C)(C)CBr)ccc1O</smiles>

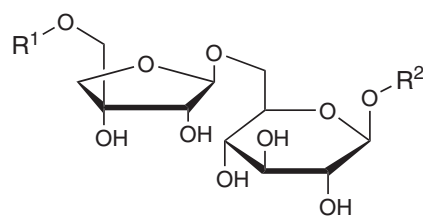
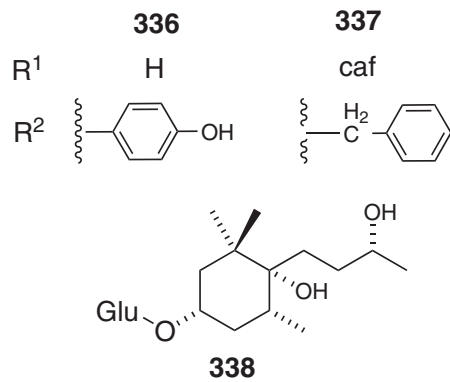

Figure 21. Quinic acid derivatives (322 to 335) and other heterosides (336 to 338) isolated and/or identified in species of the subtribe Lychnophorinae

\section{REFERENCES}

1. Mansanares, M. E.; Forni-Martins, E. R.; Semir, J.; Caryologia 2002, 55,367 .

2. Robinson, H.; P. Biol. Soc. Wash. 1992, 105, 640.

3. Robinson, H.; Smithson. Contrib. Bot. 1999, I-IV, 1.

4. Herz, W. In Compositae: Systematics. Proceedings of the International Compositae Conference, Kew; Hind, D. J. N.; Beentje, H. J., eds.; Kew, 1996, chap. 17.

5. Bastos, M.; Cerqueira, S.; Souza, J. T.; Júnior, R. A.; Peixoto, A. B. F.; Cienc. Cult. 1987, 39, 551.

6. Sousa, O. V.; Dutra, R. C.; Yamamoto, C. H.; Pimenta, D. S.; Rev. Bras. Farm. 2008, 89, 113.

7. Keles, L. C.; Gianasi, F. M.; Souza, R. C.; Brito, B. L.; Schaab, E. H.; Souza, M. G. M.; Carvalho, T. C.; Martins, C. H. G.; Veneziani, R. C. S.; Cunha, W. R.; Crotti, A. E. M.; Nat. Prod. Res. 2011, 25, doi: 10.1080/14786410903533612.

8. Bohlmann, F.; Zdero, C.; King, R. M.; Robinson, H.; Phytochemistry 1980, 19, 2663.

9. Lequesne, P. W.; Menachery, M. D.; Pastore, M. P.; Kelley, C. J.; Brennan, T. F.; Onan, K. D.; Raffauf, R. F.; Weeks, C. M.; J. Org. Chem. 1982, 47,1519
10. Pettit, G. R.; Herald, D. L.; Cragg, G. M.; Rideout, J. A.; Brown, P.; J. Nat. Prod. 1990, 53, 382.

11. Borsato, M. L. C.; Grael, C. F. F.; Souza, G. E. P.; Lopes, N. P.; Phytochemistry 2000, 55, 809.

12. Dos Santos, M. D.; Gobbo-Neto, L.; Albarella, L.; de Souza, G. E. P.; Lopes, N. P.; J. Ethnopharmacol. 2005, 96, 545.

13. Bohlmann, F.; Zdero, C.; Robinson, H.; King, R. M.; Phytochemistry 1980, 19, 2381.

14. Bohlmann, F.; Muller, L.; King, R. M.; Robinson, H.; Phytochemistry 1981, 20, 1149

15. Dos Santos, P. A.; Lopes, J. L. C.; Lopes, N. P.; Biochem. Syst. Ecol. 2004, 32, 509.

16. Bohlmann, F.; Zdero, C.; Robinson, H.; king, R. M.; Phytochemistry 1981, 20, 731.

17. Chicaro, P.; Pinto, E.; Colepicolo, P.; Lopes, J. L. C.; Lopes, N. P.; Biochem. Syst. Ecol. 2004, 32, 239.

18. Gobbo-Neto, L.; Santos, M. D.; Kanashiro, A.; Almeida, M. C.; Lucisano-Valim, Y. M.; Lopes, J. L. C.; Souza, G. E. P.; Lopes, N. P.; Planta Med. 2005, 71, 3.

19. Sakamoto, H. T.; Flausino, D.; Castellano, E. E.; Stark, C. B. W.; Gates, P. J.; Lopes, N. P.; J. Nat. Prod. 2003, 66, 693.

20. Sargenti, S. R.; Vichnewski, W.; Phytochem. Anal. 2000, 11, 69.

21. Bohlmann, F.; Zdero, C.; Robinson, H.; King, R. M.; Phytochemistry 1982, 21, 1087

22. Bohlmann, F.; Jakupovic, J.; Plant Syst. Evol. 1990, 4 (suppl.), 3.

23. Emerenciano, V. P.; Ferreira, Z. S.; Kaplan, M. A. C.; Gottlieb, O. R.; Phytochemistry 1987, 26, 3103; Da Costa, F. B.; Terfloth, L.; Gasteiger, J.; Phytochemistry 2005, 66, 345.

24. Lequesne, P. W.; Levery, S. B.; Menachery, M. D.; Brennan, T. F.; Raffauf, R. F.; J. Chem. Soc. Perkin Trans. 1 1978, 1572.

25. Sass, D. C.; Heleno, V. C. G.; Lopes, J. L. C.; Constantino, M. G.; Tetrahedron Lett. 2008, 49, 3877.

26. Gobbo-Neto, L.; Lopes, N. P.; J. Agr. Food Chem. 2008, 56, 1193

27. Gobbo-Neto, L.; dos Santos, M. D.; Albarella, L.; Zollo, F.; Pizza, C.; Lopes, N. P.; Biochem. Syst. Ecol. 2008, 36, 473.

28. Moraes, S. L.; Gregorio, L. E.; Tomaz, J. C.; Lopes, N. P.; Chromatographia 2009, 69 (suppl. 2), S157.

29. Guzzo, L. S.; Saude-Guimaraes, D. A.; Silva, A. C. A.; Lombardi, J. A.; Guimaraes, H. N.; Grabe-Guimaraes, A.; J. Ethnopharmacol. 2008, 116, 120.

30. Schmidt, T. J.; Bioorgan. Med. Chem. 1997, 5, 645.

31. Grael, C. F. F.; Vichnewski, W.; de Souza, G. E. P.; Lopes, J. L. C.; Albuquerque, S.; Cunha, W. R.; Phytother. Res. 2000, 14, 203.

32. Jordao, C. O.; Vichnewski, W.; De Souza, G. E. P.; Albuquerque, S.; Lopes, J. L. C.; Phytother. Res. 2004, 18, 332.

33. Rungeler, P.; Castro, V.; Mora, G.; Goren, N.; Vichewski, W.; Pahl, H. L.; Merfort, I.; Schmidt, T. J.; Bioorgan. Med. Chem. 1999, 7, 2343.

34. Dos Santos, M. D.; Chen, G.; Almeida, M. C.; Soares, D. M.; Souza, G. E. P.; Lopes, N. P.; Lantz, R. C.; Nat. Prod. Comm. 2010, 5, 733.

35. Nascimento, A. M. A.; Brandao, M. G. L.; Oliveira, G. B.; Fortes, I. C. P.; Chartone-Souza, E.; Anton. Leeuw. Int. J. G. 2007, 92, 95.

36. Sousa, O. V.; Silverio, M. S.; Del-Vechio-Vieira, G.; Matheus, F. C.; Yamamoto, C. H.; Alves, M. S.; J. Pharm. Pharmacol. 2008, 60, 771.

37. Oliveira, A. B.; Saude, D. A.; Perry, K. S. P.; Duarte, D. S.; Raslan, D. S.; Boaventura, M. A. D.; Chiari, E.; Phytother. Res. 1996, 10, 292.

38. Saúde-Guimarães, D. A.; Faria, A. R.; Rev. Bras. Farmacogn. 2007, 17, 455.

39. Takeara, R.; Albuquerque, S.; Lopes, N. P.; Lopes, J. L. C.; Phytomedicine 2003, 10, 490

40. Edwirds, J. M.; Raffauf, R. F.; Le Quesne, P. W.; J. Nat. Prod. 1979, 42, 85.

41. Herz, W.; Kumar, N.; Vichnewski, W.; Blount, J. F.; J. Org. Chem. 1980, $45,2503$. 
42. Lequesne, P. W.; Pastore, M. P.; Raffauf, R. F.; Lloydia 1976, 39, 391.

43. Vasconcellos, M. C.; Rosa, R. M.; Machado, M. S.; Villela, I. V.; Crotti, A. E. M.; Lopes, J. L. C.; Pessoa, C.; Moraes, M. O.; Lopes, N. P.; Costa-Lotufo, L. V.; Saffi, J.; Henriques, J. A. P.; Mutat. Res. 2007, 631, 16.

44. Silvério, M. S.; Souza, O. V.; Leite, M. N.; Eur. J. Pharm. Sci. 2001, 13, 103.

45. Ferraz, S. O.; Dutra, R. C.; Yamamoto, C. H.; Pimenta, D. S.; Souza, O. V.; Abstracts, XII Meeting of Scientific Initiation, Juiz de Fora, Brazil, 2006.

46. Vichnewski, W.; Skrochy, C. A.; Maria, A.; Nasi, T. T.; Lopes, J. L. C.; Herz, W.; Phytochemistry 1999, 50, 317; Matos, M. E. O.; de Souza, M. P.; Matos, F. J. A.; Craveiro, A. A.; J. Nat. Prod. 1988, 51, 780.

47. Heleno, V. C. G.; Sakamoto, H. T.; Crotti, A. E. M.; Lopes, N. P.; Vichnewski, W.; Lopes, J. L. C.; Nat. Prod. Comm. 2010, 5, 681.

48. Sacilotto, A. C. B. C.; Doctoral Thesis, University of São Paulo, Brazil, 2000.

49. Bohlmann, F.; Singh, P.; Zdero, C.; Ruhe, A.; King, R. M.; Robinson, H.; Phytochemistry 1982, 21, 1669.

50. Sakamoto, H. T.; Doctoral Thesis, University of São Paulo, Brazil, 2004.

51. Mauro, M. R. V.; Tucci, A. M.; Nasi, A. M.; Nasi, T. T.; J. Braz. Chem. Soc. 1993, 4, 30; Vichnewski, W.; Gilbert, B.; Phytochemistry 1972, 11 , 2563.

52. Raffauf, R. F.; Huang, P. C.; Le Quesne, P. W.; Levery, S. B.; Brennan, T. F.; J. Am. Chem. Soc. 1975, 97, 6884.

53. Vichnewski, W.; Takahashi, A. M.; Nasi, A. M. T.; Goncalves, D.; Dias, D. A.; Lopes, J. N. C.; Goedken, V. L.; Gutierrez, A. B.; Herz, W.; Phytochemistry 1989, 28, 1441.

54. Galdino, A. P. P.; Brito, J. O.; Garcia, R. F.; Scolforo, J. R. S.; Rev. Bras. Plant. Med. 2006, 8, 44; Vichnewski, W.; Lopes, J. L. C.; Dos SantosFilho, D.; Herz, W.; Phytochemistry 1976, 15, 1775; Lima, P. D. D. B.; Garcia, M.; Rabi, J. A.; J. Nat. Prod. 1985, 48, 986.

55. Lunardello, M. A.; Tomaz, J. C.; Vichnewski, W.; Lopes, J. L. C.; Gutierrez, A. B.; Diaz, J. G.; Herz, W.; J. Braz. Chem. Soc. 1995, 6, 307.

56. Bohlmann, F.; Gupta, R. K.; Jakupovic, J.; Robinson, H.; King, R. M.; Phytochemistry 1981, 20, 1609.

57. Barros, D. A. D.; Lopes, J. L. C.; Vichnewski, W.; Lopes, J. N. C.; Kulanthaivel, P.; Herz, W.; Planta Med. 1985, 51, 38.

58. Vichnewski, W.; Welbaneide, F.; Machado, L.; Rabi, J. A.; Murari, R.; Herz, W.; J. Org. Chem. 1977, 42, 3910; Vichnewski, W.; Sarti, S. J.; Gilbert, B.; Herz, W.; Phytochemistry 1976, 15, 191.

59. Asakawa, Y.; Taira, Z.; Toyota, M.; Takemoto, T.; J. Org. Chem. 1981, 46, 4602.

60. Andrade, I. L.; Bezerra, J. N. S.; Lima, M. A. A.; De Faria, R. A. P. G.; Lima, M. A. S.; Andrade-Neto, M.; J. Agr. Food Chem. 2004, 52, 5879.

61. Sakamoto, H. T.; Gobbo-Neto, L.; Cavalheiro, A. J.; Lopes, N. P.; Lopes, J. L. C.; J. Braz. Chem. Soc. 2005, 16, 1396.

62. Saciloto, A. C. B. C.; Sartori, F. T.; Vichnewski, W.; Biochem. Syst. Ecol. 2002, 30, 897 .

63. Lequesne, P. W.; Menachery, M. D.; Raffauf, R. F.; J. Nat. Prod. 1979, 42, 320; Raffauf, R. F.; Pastore, M. P.; Kelley, C. J.; Le Quesne, P. W.; Miura, I.; Nakanishi, K.; Finer, J.; Clardy, J.; J. Am. Chem. Soc. 1978, 100, 7437

64. Bohlmann, F.; Zdero, C.; King, R. M.; Robinson, H.; Phytochemistry 1980, 19, 2669.

65. Bazon, J. N.; Lopes, J. L. C.; Vichewski, W.; Lopes, J. L. C.; Fitoterapia 1997, LXVIII, 92.

66. Bohlmann, F.; Zdero, C.; Robinson, H.; King, R. M.; Phytochemistry 1982, 21, 685 .

67. Da Costa, F. B.; Dias, D. A.; Lopes, J. L. C.; Vichnewski, W.; Phytochemistry 1993, 34, 261.

68. Borella, J. C.; Lopes, J. L. C.; Vichnewski, W.; Cunha, W. R.; Herz, W.; Biochem. Syst. Ecol. 1998, 26, 671.
69. Gobbo-Neto, L.; Doctoral Thesis, University of São Paulo, Brazil, 2007; Curado, M. A.; Oliveira, C. B. A.; Jesus, J. G.; Santos, S. C.; Seraphin, J. C.; Ferri, P. H.; Phytochemistry 2006, 67, 2363; Moraes, S. L.; Tomaz, J. C.; Lopes, N. P.; Biomed. Chromatogr. 2007, 21, 925; Lopes, N. P.; Biológico 2003, 65, 67; Da Costa, M. A. C.; Jesus, J. G.; Farias, J. G.; Nogueira, J. C. M.; Oliveira, A. L. R.; Ferri, P. H.; Rev. Biol. Neotrop. 2008, 5, 53; Lyra, C.; Vieira, R. F.; de Oliveira, C. B. A.; Santos, S. C.; Seraphin, J. C.; Ferri, P. H.; J. Braz. Chem. Soc. 2008, 19,842 .

70. Moraes, S. L.; Carollo, C. A.; Tomaz, J. C.; Lopes, N. P.; Anal.Chem. Indian J. 2007, 4, 54.

71. Sartori, F. T.; Barrachia, A. C.; Sacilotto, C.; Lopes, J. L. C.; Lopes, N. P.; Vichnewski, W.; Biochem. Syst. Ecol. 2002, 30, 609.

72. Vichnewski, W.; Lins, A. P.; Herz, W.; Murari, R.; Phytochemistry 1980, $19,685$.

73. Silveira, D.; de Souza Filho, J. D.; de Oliveira, A. D.; Raslan, D. S.; Ecletica Quim. 2005, 30, 37.

74. Grael, C. F. F.; Albuquerque, S.; Lopes, J. L. C.; Fitoterapia 2005, 76, 73.

75. Alves, K. C. M.; Gobbo-Neto, L.; Lopes, N. P.; Biochem. Syst. Ecol. 2008, 36, 434 .

76. Cunha, W. R.; Lopes, J. L. C.; Vichnewski, W.; Diaz, J. G.; Herz, W.; Phytochemistry 1995, 39, 387.

77. Taleb-Contini, S. H.; Santos, W. F.; Mortari, M. R.; Lopes, N. P.; Lopes, J. L. C.; Basic Clin. Pharmacol. 2008, 102, 281.

78. Miguel, O. G.; Lima, E. O.; Morais, V. M. F.; Gomes, S. T. A.; DelleMonache, F.; Cruz, A. B.; Cruz, R. C. B.; Cechinel, V.; Phytother. Res. 1996, 10, 694.

79. Bohlmann, F.; Zdero, C.; King, R. M.; Robinson, H.; Liebigs Ann. Chem. 1983, 8, 1455.

80. Saúde, D. A.; Barrero, A. F.; Oltra, J. E.; Justicia, J.; Raslan, D. S.; Silva, E. A.; Rev. Bras. Farmacogn. 2002, 12, 7.

81. Saude, D. A.; Rasland, D. S.; De Souza, J. D.; De Oliveira, A. B.; Fitoterapia 1998, 69, 90.

82. Tavares, K. G.; Doctoral Thesis, Federal University of Minas Gerais, 1990.

83. Crotti, A. E. M.; Cunha, W. R.; Lopes, N. P.; Lopes, J. L. C.; J. Braz. Chem. Soc. 2005, 16, 677; Crotti, A. E. M.; Do Sim, P. C.; Lopes, N. P.; Lopes, J. L. C.; Abstracts, $25^{\text {th }}$ Annual Meeting of the Brazilian Chemical Society, Poços de Caldas, Brazil, 2002.

84. Bohlmann, F.; Wallmeyer, M.; King, R. M.; Robinson, H.; Phytochemistry 1982, 21, 1439.

85. Zdero, C.; Bohlmann, F.; Robinson, H.; King, R. M.; Phytochemistry 1981, 20, 739 .

86. Vichnewski, W.; Semir, J.; Leitão-Filho, H. F.; Nakashima, C.; Lunardello, M. A.; Gutierrez, A. B.; Herz, W.; Rev. Latinoam. Quim. 1990, 21, 28.

87. Siedle, B.; Garcia-Piñeres, A. J.; Murillo, R.; Schulte-Monting, J.; Castro, V.; Rungeler, P.; Klaas, C. A.; Da Costa, F. B.; Kisiel, W.; Merfort, I.; J. Med. Chem. 2004, 18, 6042.

88. Leite, G. O.; Rosangela da Penha, A.; Fernandes, C. N.; Souza, H. H. F.; da Costa, J. G. M.; Campos, A. R.; Fitoterapia 2009, 80, 77.

89. Trevisan, M. T. S.; Macedo, F. V. V.; Van de Meent, M.; Rhee, I. K.; Verpoorte, R.; Quim. Nova 2003, 26, 301.

90. Canalle, R.; Burim, R. V.; Lopes, J. L. C.; Takahashi, C. S.; Cancer Detect. Prev. 2001, 25, 93.

91. Dias, F. D.; Takahashi, C. S.; Sakamoto-Hojo, E. T.; Vichnewski, W.; Sarti, S. J.; Environ. Mol. Mutagen. 1995, 26, 338.

92. Yuuya, S.; Hagiwara, H.; Suzuki, T.; Ando, M.; Yamada, A.; Suda, K.; Kataoka, T.; Nagai, K.; J. Nat. Prod. 1999, 62, 22.

93. Baker, P. M.; Fortes, C. C.; Fortes, E. G.; Gazzineli, G.; Gilbert, B.; Lopes, J. N. C.; Pellegrino, J.; Tomassini, T. C.; Vichnewski, W.; J. Pharm. Pharmacol. 1972, 24, 853. 
94. Souza, O. V.; Silvério, M. S.; Oliveira, I. C. M.; Mattos, M. C.; Benchetrit, L. C.; Kaplan, M. A. C.; Abstracts, $4^{\text {th }}$ International Congress of Pharmaceutical Sciences, Ribeirão Preto, Brazil, 2003; Silvério, M. S.; Rabello, S. V.; do Carmo, M. I.; Sousa, O. V.; Oliveira, I. C. M.; Mattos, M. C.; Benchetrit, L. C.; Figueiredo, M. R.; Heringer, A. P.; Kaplan, M. A. C.; Rev. Bras. Farmacogn. 2003, 39, 248; Sousa, O. V.; Silvério, M. S.; Oliveira, I. C. M.; Mattos, M. C.; Benchetrit, L. C.; Kaplan, M. A. C.; Abstracts, III Brazilian Symposium of Pharmacognosy, Curitiba, Brazil, 2001; Silvério, M. S.; Master Dissertation, Federal University of Rio de Janeiro, Brazil, 2004; Oliveira, G. B.; Chartone-Souza, E.; Nascimento, A. M. A.; Abstracts, XXI Brazilian Congress of Microbiology, Foz do Iguaçu, Brazil, 2001; Oliveira, G. B.; Brandão, M. G. L.; Chartone-Souza, E.; Nascimento, A. M. A.; Anais da XI Semana de Iniciação Científica da Universidade Federal de Minas Gerais, Belo Horizonte, Brasil, 2002; ChartoneSouza, E.; Abstracts, Brazilian Symposium of Medicinal Plants, Manaus, Brazil, 2004.

95. Sousa, O. V.; Moreira, F. O.; Silvério, M. S.; Pinto, P. F.; Barros, R. A. M.; Kaplan, M. A. C.; Resumos do Congresso Íbero-Americano de Plantas Medicinais, Angra dos Reis, Brasil, 2004.

96. Moreira, F.; Master Dissertation, Federal University of Minas Gerais, Brazil, 2005.

97. Mendes, N. M.; Queiroz, R. O.; Grandi, T. S. M.; dos Anjos, A. M. G.; de Oliveira, A. B.; Zani, C. L.; Mem. I. Oswaldo Cruz 1999, 94, 411.

98. Frighetto, N.; Carvalho, J. E.; Antônio, M. A.; Dias, P. C.; Oliveira, J. G.; Kohn, L. K.; Resumos da XI Reunião Anual da Federação de Sociedade de Biologia Experimental, Caxambu, Brasil, 1996.

99. Tavares, C. Z.; Dutra, R. C.; Ferraz, S. O.; Sousa, O. V.; Abstracts, XII Meeting of Scientific Investigation, Juiz de Fora, Brazil, 2006; Sousa, O. V.; Tavares, C. Z.; Soares Júnior, D. T.; Dutra, R. C.; Ferraz, S. O.; Ferraz, S. O.; Campos, A. C.; Abstracts, XI Meeting of Scientific Initiation, Juiz de Fora, Brazil, 2004; Soares Júnior, D. T.; Dutra, R. C.; Ferraz, S. O.; Campos, A. C.; Silvério, M. S.; Sousa, O. V.; Abstract, XI Congress of Clinical Analysis of Minas Gerais, Juiz de Fora, Brazil, 2004.
100. Sousa, O. V.; Domingues, E. C.; Moreira, F. O.; Resumos da I Mostra de Trabalhos de Graduação da Universidade Federal de Juiz de Fora, Juiz de Fora, Brasil, 2003; Frighetto, N.; Oliveira, J. G.; Carvalho, J. E.; Nogueira, D. C. F.; Dias, P. C.; Mendonça, C. J. S.; Antônio, M. A.; Abstracts, XI Annual Meeting of the Federation of Societies of Experimental Biology, Caxambú, Brazil, 1996; Frighetto, N.; Oliveira, J. G.; Carvalho, J. E.; Possenti, A.; Dias, P. C.; Nogueira, D. C. F.; Abstract, III Paulist Congress of Medicinal Plants, Campinas, Brazil, 1997; Frighetto, N.; Oliveira, J. G.; Carvalho, J. E.; Possenti, A.; Mendonça, C. J. S.; Dias, P. C.; Nogueira, D. C. F.; Abstracts, XIII Annual Meeting of the Federation of Societies of Experimental Biology, Caxambú, Brazil, 1998.

101. Barth, L. R.; Fernandes, A. P. M.; Ribeiro Paes, J. T.; Rodrigues, V.; Mem. I. Oswaldo Cruz 1997, 92, 427.

102. Bazon, J. N.; Master Dissertation, University of São Paulo, Brazil, 1997.

103. Dos Santos, P. A.; Amarante, M. F. C.; Pereira, A. M. S.; Bertoni, B.; Franca, S. C.; Pessoa, C.; de Moraes, M. O.; Costa-Lotufo, L. V.; Pereira, M. R. P.; Lopes, N. P.; Chem. Pharm. Bull. 2004, 52, 1433.

104. Kanashiro, A.; Kabeya, L. M.; Polizello, A. C. M.; Lopes, N. P.; Lopes, J. L. C.; Lucisano-Valim, Y. M.; Phytother. Res. 2004, 18, 61.

105. Filha, Z. S. F.; Vitolo, I. F.; Fietto, L. G.; Lombardi, J. A.; SaudeGuimaraes, D. A.; J. Ethnopharmacol. 2006, 107, 79.

106. Salvador, M. J.; Sartori, F. T.; Sacilotto, A.; Pral, E. M. F.; Alfieri, S. C.; Vichnewski, W.; Z. Naturforsch. C 2009, 64, 509.

107. Chiari, E.; Duarte, D. S.; Raslan, D. S.; Saúde, D. A.; Perry, K. G.; Phytother. Res. 1996, 10, 636.

108. Silveira, D.; Wagner, H.; Chiari, E.; Lombardi, J. A.; Assunção, A. C.; Oliveira, A. B.; Raslan, D. S.; Rev. Bras. Farmacogn. 2005, 15, 294.

109. Silva, M. Q. O. R.; Guedes, V. R.; Young, C. M.; Martins, D.; Abstracts, $22^{\text {nd }}$ Annual Meeting of the Brazilian Chemical Society, Poços de Caldas, Brazil, 1999. 